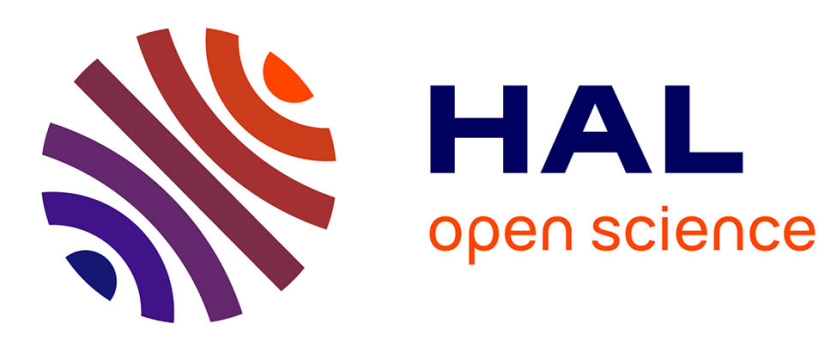

\title{
The Sale of Failed Banks: The Characteristics of Acquirers -as Well as of the Acquired -Matter
}

Pejman Abedifar, Amine Tarazi, Lawrence J White

\section{To cite this version:}

Pejman Abedifar, Amine Tarazi, Lawrence J White. The Sale of Failed Banks: The Characteristics of Acquirers -as Well as of the Acquired -Matter. 2020. hal-02964631

\section{HAL Id: hal-02964631 \\ https://hal-unilim.archives-ouvertes.fr/hal-02964631}

Preprint submitted on 12 Oct 2020

HAL is a multi-disciplinary open access archive for the deposit and dissemination of scientific research documents, whether they are published or not. The documents may come from teaching and research institutions in France or abroad, or from public or private research centers.
L'archive ouverte pluridisciplinaire HAL, est destinée au dépôt et à la diffusion de documents scientifiques de niveau recherche, publiés ou non, émanant des établissements d'enseignement et de recherche français ou étrangers, des laboratoires publics ou privés. 


\title{
The Sale of Failed Banks: The Characteristics of Acquirers - as Well as of the Acquired - Matter
}

\author{
Pejman Abedifara ${ }^{\mathrm{a}, \mathrm{b}, 1}$, Amine Tarazi ${ }^{\mathrm{c}, \mathrm{d}}$, Lawrence J. White \\ ${ }^{a}$ Tehran Institute for Advanced Studies, Khatam University, Tehran, Iran \\ ${ }^{b}$ Centre for Responsible Banking \& Finance, School of Management, University of St Andrews, UK \\ ${ }^{c}$ Université de Limoges, LAPE, 5 rue Félix Eboué, 87031 Limoges, France \\ ${ }^{d}$ Institut Universitaire de France (IUF), 1 rue Descartes, 75231 Paris, France \\ e Stern School of Business, New York University, New York, NY 10012-1126, USA
}

\begin{abstract}
This paper studies the pricing of assets and the franchise value that is embedded in the core deposits and branches of insolvent banks that are sold under the purchase and assumption resolution method of the Federal Deposit Insurance Corporation (FDIC). We analyze 620 acquisitions of solvent and insolvent U.S. banks between 2007:Q1 and 2016:Q3 and find that acquirers pay higher prices for insolvent banks with more branches. However, acquirers with more employees pay lower premiums for assuming core deposits of insolvent banks. We also compare the financial strength of acquirers of failed banks with that of acquirers of healthy banks in non-assisted takeovers. The results show that being financially strong matters more to acquire a solvent bank than a failed bank. Our findings have important implications for policy makers.
\end{abstract}

JEL Classifications: G21, G28

Keywords: Bank failures, Resolution, FDIC.

Acknowledgement: We gratefully acknowledge research assistance and excellent data collection work by Dr Fazel Moridi Farimani. We also acknowledge funding for data by the School of Management, University of St Andrews.

\footnotetext{
${ }^{1}$ Corresponding author. E-mail addresses: pa31@st-andrews.ac.uk (P. Abedifar); amine.tarazi@unilim.fr (A. Tarazi); Lwhite@stern.nyu.edu (L. White).
} 


\section{Introduction}

In the U.S., the Federal Deposit Insurance Corporation (FDIC) resolves failed (insolvent) federally insured depository institutions by selling their assets and deposits to healthy financial institutions -- which are known as assuming institutions -- under a purchase and assumption (P\&A) transaction. The primary objectives of the FDIC are to provide immediate liquidity to the insured depositors of failed banks and to minimize the expected losses to the deposit insurance fund.

The sale of a failed bank is conducted in the form of an auction: Eligible acquirers are invited by the FDIC to attend the auction and to bid for the failed bank. The bidders are supposed to offer two bids: a discount for purchasing the assets, and a premium for assuming the deposits. In some cases, the FDIC commits to bear a proportion of future losses on certain assets under a loss-share agreement. The FDIC assesses the bids and chooses the one that is the least costly to the deposit insurance fund (Resolutions Handbook 2014, pp. 2, 5). Assets and deposits of the insolvent bank are then transferred to the winning bidder. The resolution process is fast and takes place within a few days, ${ }^{2}$ with only a few weeks of prior planning by the FDIC staff.

The key question is whether, in such a short period, the FDIC sells assets and deposits of failed banks at a fair price and to the right acquirers. Most previous studies show that the assuming institutions' share prices experience positive abnormal returns (James and Wier, 1987; Bertin, Ghazanfari and Torabzadeh, 1989; Cochran, Rose, and Fraser, 1995; Zhang, 1997 and Loveland, 2012), ${ }^{3}$ which implies that the assets and deposits of failed banks are underpriced.

\footnotetext{
${ }^{2}$ Typically, the insolvent bank is closed on a Friday afternoon, then reopened as a branch of the acquiring bank on a Monday morning.

3 James and Wier (1987), using a sample of nineteen P\&A auctions for the 1973-1983 period, find positive abnormal returns for the acquirers and claim that winning bidders in P\&A deals pay less than the true value of the failed banks. Bertin, Ghazanfari, and Torabzadeh (1989) study 33 P\&A deals during the 1982-1987 period and report positive cumulative abnormal returns for winning bidders and argue that their bids are, on average, less than the value of failed
} 
In this paper, we extend this literature by modeling acquisition price as a function of target bank core deposits, number of branches, non-performing loans, inefficiency, commercial mortgages, market share, and size. We also consider indicators of the financial strength and efficiency of acquirers in our model. Indeed, if the acquiring bank is financially weaker or less efficient, it is less likely to exploit its new assets and core deposit base appropriately, and as a result such acquirers tend to offer a lower price. Granja, Matvos, and Seru (2017) study the allocation of failed banks and find that thinly capitalized potential acquirers have less ability to acquire failed banks and this distorts the allocation of failed banks towards the acquirers that may have a lower willingness to pay.

We use data on 234 acquisitions of insolvent banks (arranged by the FDIC) and 386 acquisitions of solvent banks that took place between 2007:Q1 and 2016:Q3. The acquisition price in the insolvent bank deals is the premium that is paid to assume the deposits, minus: a) the discount that the acquirer receives for purchasing troubled assets; and b) the expected value of the FDIC's commitment, if any, to share some of the future losses under the loss-share agreement. Our sample of failed bank acquisitions shows that acquirers pay on average a $0.35 \%$ premium to assume failed banks' core deposits and receive on average a $13.68 \%$ discount for purchasing the assets of failed banks. The value of a loss-share agreement is on average $2.93 \%$ of failed banks' total assets.

banks. Cochran et al. (1995) examine 58 P\&A auctions during the 1982-1991 period and find that P\&A dealers have experienced positive abnormal returns, especially when both acquirers and the failed banks are large. The acquirers of small failed banks have not earned a positive significant excess return. Zhang (1997) studies 128 FDIC assisted acquisitions and 387 non-assisted acquisitions and claims that the repeated assisted acquirers have gained positive abnormal returns, while first-time acquirers have not exhibited positive excess returns. Finally, Loveland (2012) analyzes 225 P\&A transactions during 1985-2010 and finds positive abnormal returns for the winning bidders. He claims that failed banks' auctions take place when the banking industry is in distress and in lack of liquidity which causes failed banks to be sold at a discount (fire-sale hypothesis). The information asymmetry hypothesis may also explain the underpricing of failed banks. In contrast, Pettway and Trifts (1985) report a negative average geometric abnormal return for a sample of eleven P\&A transactions that occurred from 1975 through 1981 . They conclude that acquirers overbid for failed banks. 
We first study the franchise value $e^{4}$ that is embedded in the core deposits and in the number of branches of insolvent banks that are sold under the P\&A resolution method. After controlling for target bank non-performing loans, inefficiency, market share, and time effects, we find no significant relationship between the core deposits of insolvent banks and their price-to-assets ratio. However, we do find that failed banks with more branches are sold, on average, at a higher price, which suggests that there is a premium that acquirers pay so as to benefit from broader geographic coverage. In our preferred specification, a one percent increase in the number of branches is associated with a $1.79 \%$ increase in the price-to-assets ratio. Such results suggest that the franchise value of a failed bank is not necessarily embedded in its amount of core deposits but rather in its branch network. Our findings hence highlight a premium for geographic expansion as captured by branching rather than by core deposits.

Next, we explore whether financial weakness or inefficiency of the acquirers can also affect acquisition prices. Our analysis shows that there is a significantly negative relationship between cost inefficiency of acquirers -- in particular, employees' salaries and expenditures -- and the prices that they offer to acquire either solvent or insolvent banks. This relationship could be spurious, because in less competitive auctions, acquisition prices and the efficiency of acquirers are both expected to be low. To address this concern, we control for the number of bidders in the auctions that are organized by the FDIC. The negative link between acquirer inefficiency and the acquisition price persists. In addition, the price increases with the number of bidders. Further investigation shows that acquirers with more employees pay lower premiums for the core deposits of failed

\footnotetext{
${ }^{4}$ Franchise value is an intangible asset and is, in general, difficult to accurately measure. However, a key component of the franchise value of banks is associated with bank-client relationship (see Demsetz, Saidenberg, and Strahan 1996; Ergungor 2005; Liang, Ching and Chan 2013; Santikian 2014; among others). Bank-client relationship can be represented by branch networks and core deposits. Branches are the selling points where banks interact with their clients. The literature shows that banks establish branches, even abroad, to maintain the relationships with their clients (Williams 2002) and core deposits are a source of stable funds that are built up gradually over time.
} 
banks, which suggests that the FDIC might prefer to allocate failed banks to acquirers with more officers to better serve depositors of failed banks.

Given the results on the link between acquirers' inefficiency and acquisition prices, we examine the financial strength and efficiency of acquirers of failed banks. Acquirers of failed banks are expected to be financially strong, and must meet certain criteria to be eligible for bidding. They must be well capitalized, possess an acceptable CAMELS $^{5}$ rating, and have a satisfactory compliance record (Granja et al. 2017). Nevertheless, Igan, Lambert, Wagner, and Zhang (2017) show that bidding banks that engage in lobbying activities have a higher probability of winning the auctions that are organized by the FDIC, which casts doubt on strict adherence to the criteria for selecting eligible acquirers.

In this study we assess the financial strength and efficiency of acquirers of failed banks by comparing their strength with that of acquirers of healthy banks in non-assisted takeovers. The results show that the acquirers in the FDIC-assisted acquisitions are less efficient and have higher non-performing loans than do the acquirers in non-assisted acquisitions. Nevertheless, the former are larger relative to their targets, exhibit a better CAMELS score, and have a similar capitalization. Interestingly, they are much older and rely more on non-interest income than do the acquirers of healthy banks. The gap between the acquirers of healthy and failed banks persists even when we limit the acquirers of failed banks to those with more competitive auctions. We also find that the acquirers of multiple failed banks are larger, but have on average higher non-performing loans, net interest margin and non-interest income than do the acquirers who only acquire one failed bank; by contrast the banks that takeover multiple healthy targets, other than their higher net interest

\footnotetext{
${ }^{5}$ This is a supervisory rating system for assessing a bank's financial condition. It consists of Capital adequacy, Asset quality, Management, Earnings, Liquidity, and Sensitivity.
} 
margin, tend to have similar characteristics as compared to the banks that acquire only one healthy bank.

The paper is organized as follows: Section 2 presents the data and summary statistics. Section 3 looks at how franchise value embedded in core deposits is affected by the failure resolution mechanism and the role played by the financial strength and efficiency of acquirers. Section 4 provides further investigations. It compares the financial strength and efficiency of acquirers of failed banks vis-à-vis acquirers of healthy banks, and explores the relationship between the financial strength of acquirers and the probability to engage in multiple takeovers. Finally, section 5 concludes.

\section{Data and Summary Statistics}

\subsection{Data}

We use a sample of 620 observations on acquisitions of U.S. commercial banks during 2007:Q1-2016:Q3. The sample consists of 234 FDIC-assisted acquisitions ${ }^{6}$-- wherein failed banks were sold by the FDIC under the P\&A resolution method -- and 386 non-assisted takeovers. ${ }^{7}$ We collected the data on the FDIC-assisted transactions from the FDIC website. We obtained the data on non-assisted acquisitions from the SNL database. The financial data of the banks in our sample

\footnotetext{
${ }^{6}$ We initially collected 523 FDIC-assisted transactions from the FDIC website; but because we use the SNL database to retrieve financial data some deals had to be omitted. Specifically, SNL identification numbers of 61 targets and 165 acquirers are missing, which reduced our sample size to 297 deals. We merged this database with the financial data of commercial banks and bank holding companies (BHCs). However, 6 targets could not be matched. We deleted 8 banks from our sample, because their financial data were missing. In addition, since we study the deals where acquirers purchase all of the assets and assume all of the deposits of failed banks (a "whole-bank" transaction), we excluded 49 observations on non-whole-bank P\&A deals. Hence, in our final sample, there are 234 transactions.

${ }^{7}$ We also collected the data on 2,077 non-assisted acquisitions from the SNL database. We excluded 16 thrift mergers from the sample. SNL identification numbers of 7 targets and 125 acquirers are missing; in addition for 625 deals acquisition percentages and/or deal values are missing. We also excluded 63 deals where the acquisition was less than $100 \%$ of equity capital. Our sample size is hence reduced to 1,241 acquisitions. Next, we merged the data with the database on financial data of commercial banks and BHCs, where 131 targets are not matched and hence excluded from the sample. This leads to 1,110 observations, out of which for 724 targets financial data are missing. Therefore, the final sample consists of 386 transactions.
} 
have been retrieved from the SNL database. The sample of the FDIC-assisted transactions are restricted to the deals where acquirers purchase all assets and assume all deposits of failed banks (a "whole-bank" P\&A deal). ${ }^{8}$ We also limit the sample of non-assisted acquisitions to the deals where acquirers purchase $100 \%$ of equity capital.

We also construct a database at the acquirer level. We identify acquirers of 187 failed banks and 192 healthy banks in our dataset ${ }^{9}$. We clean the samples from outliers, by winsorizing one percent of each tail. Table I describes the variables that we use in this study.

\section{[TABLE I]}

\subsection{Summary Statistics}

Table II presents the summary statistics of our sample of observations on non-assisted and FDIC-assisted deals over the 2007:Q1-2016:Q3 period. Panel A presents the descriptive statistics for 234 targets that were acquired through the FDIC-assisted acquisitions and 386 targets of nonassisted deals. The data show adequate variations in both samples. The banks that were acquired through the FDIC assisted deals have, on average, similar Size, number of branches (Number Branch) and Market Share as do the banks that were acquired though non-assisted transactions. Targets of non-assisted deals have, on average, a higher share of core deposits in total liabilities, but they have lower non-performing loans, inefficiency ratios, and commercial mortgages than do

\footnotetext{
${ }^{8}$ The bidders can bid for a proportion of assets and deposits of failed banks. The price of such bids depends on the assets and deposits that are excluded from the transaction. Since the price of such deals is not comparable with the price of whole-bank transactions, we exclude them from our sample. This exclusion criterion does not jeopardize heterogeneity in our final sample.

${ }^{9}$ Since some institutions acquired more than one target, we need to collapse data at the acquirer and quarter levels before merging it with the financial database. This reduces the sample of the FDIC-assisted and non-assisted acquisitions from 234 to 205 and from 387 to 383 observations respectively. Then, we merge our dataset with financial data; however, 36 observations (6 observations on FDIC-assisted acquisitions and 30 on non-assisted takeovers) are not matched. This leads to 199 and 353 observations on FDIC-assisted and non-assisted deals, respectively. Furthermore, for 12 acquirers of FDIC-assisted targets and for 161 acquirers in non-assisted takeovers financial data are missing. Hence, our final sample of acquirers consists of 187 acquirers in FDIC-assisted deals and 192 acquirers in non-assisted transactions.
} 
failed banks that were sold in the FDIC-assisted deals. The Equity Asset Ratio is $1.24 \%$ for banks acquired through FDIC-assisted deals, whereas the ratio is about $11 \%$ for targets of non-assisted acquisitions. Targets of non-assisted acquisitions have a higher non-interest income, and they are older on average than failed banks.

The ratio of the acquisition price to total assets (Price Asset Ratio) is, on average, $14.25 \%$ for non-assisted deals, while the ratio is $-14.9 \%$ for the FDIC-assisted transactions. The figures on the FDIC-assisted deals show that the acquirers pay a $0.35 \%$ premium for assuming failed banks' deposits; they receive, on average, a $13.68 \%$ discount on the purchase of the failed banks' (nominal) assets, and the value of loss-share agreement is on average $2.93 \%$ of total assets of failed banks. On average, nearly 3 bidders attended the auctions that were organized by the FDIC. The number of bidders in such auctions ranged between 1 to 8 . The figures on Same County show that in $10 \%$ of acquisitions of healthy targets and $9 \%$ of acquisitions of failed targets, both the acquirer and the target were located in the same county.

Panel B reports the descriptive statistics of the acquirers of failed and healthy banks. Acquirers are classified into two groups: commercial banks, and BHCs. All failed banks are acquired by commercial banks, whereas in our sample 32 healthy targets are acquired by commercial banks, and the acquirers in the remaining transactions are BHCs. ${ }^{10}$

The first part of Panel B illustrates the summary statistics of the commercial banks that acquired failed and healthy banks. The data show that the acquirers of failed banks (Failed Banks Acquirers) were, on average, larger in both absolute and relative terms than the acquirers of healthy banks (Healthy Banks Acquirers). Acquirer Relative Size for acquisition of failed banks indicates

\footnotetext{
${ }^{10}$ Many of the commercial banks in our sample belong to BHCs. Nonetheless, we distinguish the acquirers that are commercial banks from BHCs to be able to compare the financial strength of acquirers in assisted acquisition vis-àvis non-assisted acquisitions.
} 
that acquirers were on average 12 times larger than failed banks. This variable ranges between 0.23 and 157. ${ }^{11}$ Failed Banks Acquirers also had more branches (Acquirer Branch) than did Healthy Banks Acquirers. There is little difference between the two groups of banks in terms of Tier 1 Ratio, Inefficiency, ${ }^{12}$ Core Deposits, and Net Interest Margin.

The panel also presents the decomposition of Acquirer Inefficiency: 1) the ratio of acquirer's salaries and benefits to total operating revenue (Acquirer Labor Cost); and 2) the ratio of acquirer's occupancy and equipment expenses and other non-interest expenses to total operating revenue (Acquirer Other Expenses). Interestingly, Healthy Banks Acquirers have a higher Acquirer Labor Cost than Failed Banks Acquirers, whereas Acquirer Other Expenses is not significantly different across the two groups of acquirers. Healthy Banks Acquirers have, on average, a lower ratio of the number of full-time employees to total operating revenue (Acquirer Employees) than do Failed Banks Acquirers; however, the former pay significantly higher salaries and benefits to their employees (Acquirer Wage) than do Failed Banks Acquirers. Failed Banks Acquirers have a lower CAMELS Score but a higher Non-Performing Loans than Healthy Banks Acquirers.

Failed Banks Acquirers have, on average, a higher Non-Interest Income and are much older than Healthy Banks Acquirers. Number of takeovers (Acquisition Number) by Healthy Banks Acquirers is on average 1.44 and ranging between 1 and 3. The figure on Acquisition Quarter

\footnotetext{
${ }^{11}$ The minimum value of Acquirer Relative Size is related to three acquisitions: The acquisitions of Cooperative Bank, Southern Community Bank, and USA Bank by First Bank, United Community Bank, and New Century Bank, respectively. The acquisitions took place in June 2009 for the first two deals and July 2010 for the last deal. However, Granja et al. (2017) state that the FDIC sets a threshold for size that depends on geographic proximity. The bidder's size must be twice of that of the failed bank if they are located in the same state. The bidders from other states must be even larger: four times larger if they are located in contiguous states, and five times otherwise.

12 "Inefficiency" is the traditional label that is given to the ratio of non-interest expense to total revenue. It clearly derives from an era when banks' functions were perceived as primarily making loans and gathering deposits. As we suggest below, to the extent that banks also earn income from fee-based activities that require additional personnel and other resources, the identification of this ratio with "inefficiency" is weakened.
} 
shows that there is no commercial bank that acquires more than one healthy target in a given quarter. However, the average Acquisition Number for Failed Banks Acquirers is 2.79 and lies between 1 and 12. Moreover, the average number of acquisitions by Failed Banks Acquirers in a given quarter is 1.14 and it ranges between 1 and 6 .

The second part of Panel B presents the summary statistics of BHCs that have acquired 160 healthy targets. As expected, they are much larger, have more branches and have a higher Non-Interest Income than do the commercial banks that have acquired failed or healthy targets. Tier 1 Ratio of BHCs is on average $13.94 \%$ which is slightly lower than that of the commercial banks reported in the first part of the pane ${ }^{13}$. In our sample, BHCs have a higher Non-performing Loans relative to the commercial banks that acquire healthy targets; yet it is still far below that of the commercial banks that take over failed banks. The Acquisition Number for BHCs is, on average, 1.51 and it ranges between 1 and 4. On average, they take over 1.02 targets in a given quarter.

[TABLE II]

\section{Does Franchise Value Survive Failure?}

We consider the following pooled cross-sectional regression model for our analysis: In this model, we define the value of targets as a function of a dummy variable for the FDIC-assisted acquisitions, core deposits, number of branches, a set of control variables (Target Controls), and year fixed effects.

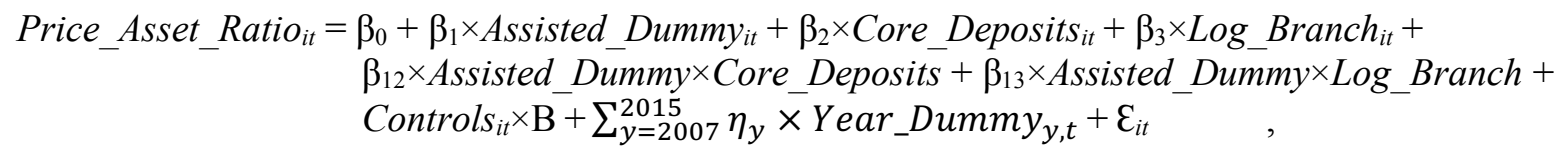

\footnotetext{
${ }^{13}$ CAMELS scores are not available for BHCs.
} 
where the individual bank and time dimension are represented by $\mathrm{i}$ and $\mathrm{t}$ subscripts, respectively. The main variables are defined as follows:

Price Asset Ratio $=100 \times$ [value of acquired bank] / [total assets of acquired bank]. The numerator is the price paid by the acquirer at the announcement date of acquisition, for the nonassisted deals. For the FDIC-assisted transactions, the numerator is the summation of the discount received for the purchase of total assets and the premium paid for assumption of deposits. The discount takes a negative value, but the premium is a positive number. For the deals with a lossshare agreement, we add the value of the loss-share agreement to the numerator with a negative sign. The value of the loss-share agreement is the product of the percentage of the loss share agreement (tranche), loss share amount and probability of loss. The first two items are obtained from the FDIC website and the last item is estimated by calculating the average net charge-off on the gross loans ratio of failed banks over their last four quarters of operation.

Assisted Dummy Variable = A dummy variable that is equal to one for the FDIC-assisted acquisitions, and zero otherwise. It is important to include the Assisted Dummy to absorb unquantifiable differences between the values of the targets in the FDIC-assisted and non-assisted acquisitions.

Core Deposits $=$ The share of core deposits in total liabilities of the target bank. Core deposits, in the Uniform Bank Performance Report (UBPR) and until March 31, 2011, ${ }^{14}$ are defined as the sum of demand deposits, all NOW and automatic transfer service (ATS) accounts, money market deposit accounts (MMDAs), other savings deposits, and time deposits under $\$ 100,000$.

\footnotetext{
${ }^{14}$ As of March 31, 2011, the definition was changed. In the new definition, insured brokered deposits are excluded from core deposits and in line with the increase in FDIC deposit insurance coverage from $\$ 100,000$ to $\$ 250,000$, the ceiling of time deposits is adjusted.
} 
Log_Branch $=$ the logarithm of Number Branch. Branches are the main conduit for interacting with clients and attracting deposits and new business opportunities (Salop 1979; Ramírez 2003; Chu 2010; Staikouras 2006; LaPlante and Paradi 2015). Branches create physical proximity and enable banks to enjoy lower transportation and monitoring costs, and execute spatial price discrimination over their clients (Petersen and Rajan 1995; Hannan and Prager 2004; Degryse and Ongena 2005) ${ }^{15}$. As for Core Deposits, we expect a positive relationship between $\log _{-}$Branch and the value of a bank.

Controls $=$ the vector of bank-level control variables. We introduce the ratio of nonperforming loans to total loans (Non-Performing Loans) as a proxy for loan quality in our model. A higher value of non-performing loans represents a lower loan quality and a higher credit risk. We control for inefficiency as the ratio of non-interest expense to total assets (Inefficiency) ${ }^{16}$. We expect targets with a higher inefficiency or higher non-performing loans to have a lower value. We include the ratio of commercial mortgages to total loans (Commercial Mortgage) in our model, because Cole and White (2012) show that banks with a higher Commercial Mortgage have a higher probability of failure. The value of a bank depends also on its market share; hence we add to the model the market share of the target in the state (Market Share). We also consider size in our analysis and represent it by the logarithm of total assets, orthogonalized on other explanatory variables. Finally, we control for time fixed effects by introducing nine annual dummy variables. ${ }^{17}$

\footnotetext{
${ }^{15}$ The literature also shows that expanded branches promote diversification in lending and funding sources (Darroch 1994 p. 84 as quoted in Chu 2010; Ramírez 2003; Carlson 2004), reduce contracting frictions, enhance capital flows across local markets (Gilje, Loutskina, and Strahan 2016), improve lending quality (Jayaratne and Strahan 1996), and increase financial stability in particular for larger banks (Hirtle and Stiroh 2007).

${ }^{16}$ We divide non-interest expense by total assets, because for failed banks operating income can be negative or be close to zero.

${ }^{17}$ The sample covers ten years: 2007-2016. We consider the year 2007 as the benchmark.
} 
To study the pricing of franchise value of failed banks, we consider the interaction term between Assisted Dummy and Core Deposits (Assisted Dummy $\times$ Core Deposits) and between Assisted Dummy and Log_Branch (Assisted Dummy $\times$ Log_Branch). It disentangles the effect of Core Deposits and Log_Branch on Price Asset Ratio for the two sub-samples of acquired banks. The coefficient of the interaction term can be:

- negative indicating that franchise value of failed banks has a lower price than that of healthy banks.

- zero indicating that franchise values of failed banks and healthy banks have a similar price.

- positive indicating that franchise value has a higher price than that of healthy banks.

Each item is a plausible outcome; nevertheless, the first one is mostly expected, since, for instance, some clients might run off to other banks after the acquisition. A zero coefficient would indicate that the franchise embedded in core deposits and branch networks is unrelated to the loan investment decisions (a Modigliani-Miller irrelevance-type result). A positive coefficient is expected if the nervous clients have already abandoned the insolvent bank, so that the remaining clients are really inertial and hence are more valuable for the acquirer.

However, this model assumes that assisted and non-assisted transactions are not fundamentally different. We test the validity of this assumption using a Chow-like F-test on join significance of interaction terms of Assisted Dummy and all other explanatory variables. ${ }^{18}$ The result indicates that we should estimate a separate regression for each sub-sample (hereinafter "preferred specification of Equation (1)"). Panel A of Table III presents the results of estimating the preferred specification of Equation (1). In column (1), we estimate the model with the use of the 386 observations on non-assisted acquisitions. We find that an increase in Core Deposits is associated with a higher Price Asset Ratio, whereas the coefficient of Log_Branch is insignificant.

\footnotetext{
${ }^{18}$ The result of the test is not reported here but is available from the authors upon request.
} 
Column (2) presents the result when we estimate the model with the use of the 234 observations on banks that were acquired through the FDIC-assisted deals. As expected, the relationships between the explanatory variables and Price Asset Ratio are different from the results in column (1). Importantly, Core Deposits does not have a significant relationship with Price Asset Ratio. One plausible explanation is that the market underprices the value of failed banks' core deposits. Another explanation could be that the embedded franchise value is destroyed for the insolvent banks that are acquired through the FDIC-assisted deals.

However, there is a significantly positive link between $L o g \_$Branch and Price Asset Ratio: Failed banks with more branches are sold at higher prices. If we assume that all other observable factors are constant, a one percent increase in the number of branches of a failed bank is associated with $1.56 \%$ increase in Price Asset Ratio. Hence, whereas core deposits matter for the acquisition of healthy banks but not that of failed banks, the opposite holds for the number of branches of acquired banks. By acquiring a failed bank with a larger number of branches a bank can expect to have a broader geographic reach; and contrary to core deposits this reach cannot be destroyed by failure.

With regard to the control variables, for non-assisted acquisitions (Column 1) there is a significantly negative relationship between Non-performing Loans and Price Asset Ratio. However, Inefficiency, Commercial Mortgage and Size exhibit no significant link with Price Asset Ratio. Banks with a higher Market Share have a higher Price Asset Ratio. The F-test shows that the coefficients of the year dummy variables are jointly significant. The coefficients reflect the change in the Price Asset Ratio for factors, which are not captured by the explanatory variables. 
All of the coefficients are significantly negative: The Price Asset Ratio significantly decreased after $2007 .^{19}$

For assisted acquisitions (Column 2) Non-performing Loans and Commercial Mortgage do not exhibit a significant relationship with Price Asset Ratio, whereas an increase in Inefficiency is associated with a lower Price Asset Ratio of failed banks. We find that failed banks with a higher Market Share and Size have on average a higher value. The coefficients of the year dummy variables are jointly significant. We find that the coefficients for the years 2009 to 2012 -- the period with the highest number of bank failures -- are significantly negative: The Price Asset Ratio of failed banks depends on the number of failures in a year, because when the number of failures increases, the investment opportunity set for acquiring banks becomes larger (Acharya and Yorulmazer 2007). ${ }^{20}$

We conduct a Blinder-Oaxaca decomposition analysis. ${ }^{21}$ The result is reported in Panel B of the table. The mean predictions of Price Asset Ratio of healthy and failed banks are presented in the first and second rows, respectively, and the difference between the means of the two groups of targets in the third row, which equals 29.15 . The difference is statistically significant at $1 \%$. The second part of the panel shows the decomposition of the difference between Price Asset Ratio of healthy and failed banks. The difference is divided into three parts. Endowments reflects that the mean value of Price Asset Ratio of failed banks would increase by $5.69 \%$ if they had the same characteristics as healthy targets. Coefficients shows a $16.78 \%$ increase in failed banks' Price Asset Ratio if we use the coefficients of the healthy banks' regression estimation, as presented in column (2), for the failed banks. Interaction reports the simultaneous impact of differences in endowments

\footnotetext{
${ }^{19}$ We consider the year 2007 as the base group.

20 There are a few failures during 2007-2008 and 2014-2016 relative to 2009-2013 timespan.

${ }^{21}$ Please refer to Blinder (1973), Oaxaca (1973) and Jann (2008) for more details.
} 
and coefficients, which is equal to $6.69 \%$. All the three parts of the difference are statistically significant at $1 \%$.

To investigate whether Price Asset Ratio is influenced by the financial condition of the acquirers, we add the following three indicators of financial strength and inefficiency of acquirers (hereinafter called "Acquirer Financials") to our preferred specification: Acquirer Tier1 Ratio = Tier 1 capital divided by total risk-weighted assets of acquirer banks; Acquirer Non-Performing Loans: the ratio of non-performing loans to total loans of acquirer banks; Acquirer Inefficiency = The ratio of total non-interest expense to total operating revenue of acquirer banks. The results for non-assisted and FDIC-assisted acquisitions are reported in columns (3) and (4), respectively. Inclusion of these variables reduces the sample size to 195 observations on non-assisted takeovers and 214 for the FDIC-assisted deals. In column (3), we find that Price Asset Ratio is not significantly affected by Acquirer Tierl Ratio and Acquirer Non-Performing Loans; however, being a less efficient acquirer is associated with a lower acquisition price. ${ }^{22} \mathrm{We}$ also observe that after introducing Acquirer Financials the coefficient of Core Deposits is no longer significant. Column (4) presents the result for FDIC-assisted deals. The results on Acquirer Financials are similar to the findings in column (3). Acquirer Tier 1 Ratio and Acquirer Non-performing Loans exhibit no significant relationship with Price Asset Ratio, whereas less efficient acquirers tend to value failed banks less. We also find that the coefficients of Market Share and Size are not significant in this specification.

In columns (5) and (6), we use the two components of Price Asset Ratio of failed banks as the dependent variable. This enables us to explore whether explanatory variables have different

${ }^{22}$ If "inefficiency" is associated with fee-based services, it may be that the acquisition of insolvent banks - which became insolvent because of failed loans - fits less well with the fee-based services. 
relationships with Deposit Premium vis-à-vis Asset Discount and Loss Share Value ${ }^{23}$. In column (5), we use the summation of Asset Discount and Loss Share Value as the dependent variable and re-estimate our model. As expected, the result is very similar to the findings in column (4).

In column (6), Deposit Premium is used as the dependent variable. We find that Deposit Premium increases with an increase in Core Deposits; however, the coefficient is significant only at the 10\% significance. Log_Branch, Non-performing Loans, Inefficiency, Commercial Mortgage and Size of failed banks exhibit insignificant relationships with Deposit Premium. In addition, we find that the acquirers tend to pay a higher Deposit Premium for the failed banks with larger Market Shares. The result on Acquirer Financials shows that an increase in Acquirer Tier 1 Ratio is associated with an increase in Deposit Premium, this is because a higher capitalization creates capacity for acquirers to assume more core deposits and therefore, they have a higher willingness to pay for it. Acquirer Non-performing Loans depicts an insignificant relationship with Deposit Premium. In line with the findings in columns (3) to (5), the result shows that more inefficient acquirers tend to pay a lower Deposit Premium. Finally, contrary to the results in columns (2) and (4), the coefficients of the year dummy variables in this specification are not significantly negative, except for the year 2016 and only at the $10 \%$ significance level. This suggests that Deposit Premium, which is relatively small, is not affected by the number of failures in a year.

\section{[TABLE III]}

We conduct several robustness checks to assess the accuracy of the significantly negative relationship between Acquirer Inefficiency and Price Asset Ratio. ${ }^{24}$ The relationship between Acquirer Inefficiency and the dependent variables across different specifications can be spurious,

\footnotetext{
${ }^{23}$ We use the summation of Asset Discount and Loss Share Value, because Loss Share Value is calculated on some classes of assets of failed banks.

${ }^{24}$ The estimations are not presented in the paper but are available from the authors upon request.
} 
because Acquirer Inefficiency may represent other financial indicators which are not included in the specifications. To address this concern, we add Acquirer CAMELS scores and Acquirer Core Deposits to the model. The results indicate that the significantly negative coefficient of Acquirer Inefficiency persists. Acquirer Inefficiency is defined as the ratio of noninterest expense to total operating income; hence, as we noted above, the "inefficiency" measure may be a proxy for the level of noninterest income activities. Therefore, we add the share of noninterest income in total operating income: Acquirer Noninterest Income; however, we find that adding this variable does not significantly change our results. In addition, we exclude Acquirer Non-performing Loans and Acquirer Tier 1 Ratio from the model to avoid potentially spurious relationships that might be driven by multicollinearity problems. ${ }^{25}$ Again, the result shows a significantly negative relationship between the Acquirer Inefficiency and the price of purchasing assets and assuming core deposits of failed banks.

Another plausible explanation is that inefficient acquirers could be located in the county of the failed banks, and the FDIC may give priority to such local and inefficient acquirers to purchase failed banks, notwithstanding their least costly resolution policy. We assess the validity of this scenario, by adding a dummy variable to the model for the acquisitions that both acquirer and failed bank are located in the same county (Same County). The result, however, indicates that the dummy variable is insignificant, and inclusion of this dummy variable does not significantly affect the relationship between Acquirer Inefficiency and acquisition price. ${ }^{26}$

\subsection{Decomposition of Acquirer's Inefficiency}

\footnotetext{
${ }^{25}$ It is worth noting that the correlations between our three indicators of financial strength are relatively low.

26 The estimations are not presented in the paper but are available from the authors upon request.
} 
In this sub-section, we use the decomposition of Acquirer Inefficiency -- Acquirer Labor Cost and Acquirer Other Expenses -- to have a closer examination of the relationship between Acquirer Inefficiency and the price of acquiring a failed bank. Table (IV) reports the results. In columns (1) and (2), we re-estimate the specification in column (4) of table (III), after replacing Acquirer Inefficiency with Acquirer Labor Cost and Acquirer Other Expenses, respectively. We find a significantly negative coefficient only for Acquirer Labor Cost.

We dig further by exploring whether the result obtained on Acquirer Labor Cost is driven by the number of employees of acquirers or the salaries of the employees. To address this question, we use Acquirer Wage and Acquirer Employees in our analysis instead of Acquirer Labor Cost. Column (3) shows that the coefficient of Acquirer Wage is statistically insignificant. However, there is a significantly negative relationship between Acquirer Employees and Price Asset Ratio (column (4)). Columns (5) and (6) present the estimations when we use Asset Discounts \& Loss Share Value and Deposit Premium, respectively, as the dependent variable. The coefficient of Acquirer Employees is significantly negative only in column (6), where we use Deposit Premium as the dependent variable. Hence, acquirers with more employees pay a lower premium to assume the core deposits of failed banks.

To check the robustness of our finding, we divide the number of employees of acquirers by total assets in lieu of total operating revenue and estimate our model. The result, which is not reported in the table, shows that the significantly negative relationship between the number of acquirers' employees and Deposit Premium holds. This relationship could be driven by an acquirer's number of branches, because one can expect that the number of employees increases with the number of branches. We address this question in the last column, by including the logarithm of Acquirer Branch (Acquirer Log_Branch) in our model. We find that Acquirer 
Log_Branch is statistically insignificant; however, the coefficient of Acquirer Employees remains significantly negative. ${ }^{27}$

\section{[TABLE IV]}

\subsection{The Role of Competition in the Auctions Organized by the FDIC}

We find a persistently negative relationship between the inefficiency of acquirers and the price of acquiring a target. Further analysis shows that acquirers with more employees tend to pay a lower premium to assume the deposits of failed banks. One plausible explanation for the result is that in less competitive auctions, the acquisition price is lower and at the same time less efficient/overstaffed banks may win the auction.

In order to examine the validity of this scenario, we include the number of bidders (Number Bidders), as a proxy for competition, to our specifications in columns (4) to (6) of table (IV). We present the results in Table (V). We use Price Asset Ratio, Asset Discounts \& Loss Share Value and Deposit Premium as the dependent variable in columns (1) to (3), respectively. The Number Bidders variable is significantly positive in all three columns, which implies that the acquirers of failed banks pay a higher Price Asset Ratio, receive a lower Asset Discount \& Loss Share Value, and pay a higher Deposit Premium in a more competitive auction. Nonetheless, the significantly negative relationship between Acquirer Employees and the dependent variable persists in column (3), where we use Deposit Premium as the dependent variable.

The economic significance of the relationship is meaningful: One more bidder attending the auction increases Price Asset Ratio, Asset Discount \& Loss Share Value, and Deposit Premium

\footnotetext{
${ }^{27}$ We also explore whether the relationship between Acquirer Employees and Deposit Premium becomes stronger with the increase in the number of branches of failed banks. We include the interaction term between $\log _{-}$Branch and Acquirer Employees in an unreported regression and find that the coefficient of the interaction term is statistically insignificant.
} 
by about $1.6 \%, 1.5 \%$, and $0.1 \%$ from the mean, respectively. A one percent increase in Acquirer Employees from the mean is associated with about $0.012 \%$ decrease in Deposit Premium. Inclusion of Number Bidders increases the economic significance of $\log _{-}$Branch to a $1.79 \%$ increase in Price Asset Ratio for one percent increase in Log_Branch.

\section{[TABLE V]}

We also investigate whether the relationship between Acquirer Employees and Deposit Premium varies with the degree of competition by including the interaction term of Acquirer Employees and the Number Bidders and find that it is statistically insignificant.

\section{Further Investigations}

We find robust evidence showing that bidders with higher labor costs pay lower prices to acquire failed banks. Also, bidders with more employees pay lower premiums to assume the core deposits of failed banks. This opens two important questions: 1) Do the efficiency and financial strength of acquirers play a role in acquiring a failed bank through the auctions that are organized by the FDIC as compared with a solvent target outside the FDIC mechanism? and 2) How important are the efficiency and financial strength of acquirers for winning the acquisition of multiple failed banks relative to the acquisition of multiple healthy targets?

\subsection{Financial Strength and Efficiency of Failed Banks' Acquirers}

In this section, we investigate whether financial strength and efficiency of acquirers matters differently when acquiring an insolvent bank and a solvent bank. Specifically, we examine the relationship between acquirers' efficiency and financial strength and the probability of acquiring insolvent banks versus solvent banks. We define a dummy variable (Assisted Acquisition) that takes the value of one for the FDIC-assisted acquisitions, and zero for non-assisted acquisitions. We define Assisted Acquisition as a function of Relative Size, Acquirer Financials, Acquirer 
Controls and year fixed effects. We estimate our pooled cross-sectional regression model using logit regressions:

$$
\begin{aligned}
\text { Assisted_Acquisition }_{i t}= & \alpha+\beta \times \text { Relative_Size }_{i t}+\text { Acquirer_Financials }_{i t} \times \Gamma+ \\
& \text { Acquirer_Controls }{ }_{i t} \times \Delta+\sum_{y=2007}^{2015} \eta_{y} \times \text { Year_Dummy }_{y, t}+\varepsilon_{i t},
\end{aligned}
$$

where the individual bank and time dimensions are represented by $i$ and $t$ subscripts, respectively. The explanatory variables are defined as follows:

Relative Size is the ratio of total assets of the acquirer to total assets of the target. Acquirer Financials includes Acquirer Tier1 Ratio, Acquirer Non-Performing Loans and Acquirer Inefficiency.

We include the following five control variables, collectively called Acquirer Controls, in our analysis: Acquirer CAMELS Score = the CAMELS score; Acquirer Core Deposits; Acquirer Net Interest Margin = interest income minus interest expense divided by total earning assets; Acquirer Non-Interest Income $=$ The income from non-interest activities divided by total operating income; $A g e=$ the difference between the current year and the year of establishment.

Table VI reports the estimation results of Equation (2) using logit regressions. We estimate the probability of acquiring a failed bank in the FDIC-assisted deals (Assisted Acquisition) versus a solvent bank as a function of financial strength of acquirers and control variables. In the first column, we use 246 observations for our analysis. The sample includes 32 non-assisted takeovers by commercial banks and 214 FDIC-assisted deals.

The results show that acquirers of failed banks tend to have a larger Relative Size as compared to the acquirers of healthy targets only at the $10 \%$ significance level. There is no significant difference between acquirers of healthy and failed banks in terms of Tier 1 Ratio. Nonetheless, we observe that the probability of success in the FDIC-assisted acquisitions is 
positively correlated with Acquirers Non-Performing Loans and Acquirers Inefficiency. ${ }^{28}$ We find that there is a negative relationship between Acquirers CAMELS Score and the Assisted Acquisition, which is in line with our expectation, given that having a good (i.e., numerically low) CAMELS rating is one of the criteria to be eligible for bidding in the FDIC auctions. Acquirer Core Deposits and Acquirer Net Interest Margin exhibit no significant relationship with the dependent variable. The result also shows that the acquirers of failed banks tend to have a higher Non-Interest Income and they are, on average, older than the acquirers of healthy targets.

Column (2) reports marginal effects at the mean. According to the result in this column, a one percent increase in Acquirer Inefficiency from the mean is associated with a $0.2 \%$ increase in probability of acquiring a failed bank. The average inefficiency of acquirers of healthy and failed banks is $68.47 \%$, and one percent of it equals $1.46 \%$. Hence, the relationship is economically meaningful.

In columns (3) and (4), we examine whether in more competitive auctions for selling failed banks, acquirers of failed banks are more efficient and financially stronger than the acquirers in non-assisted acquisitions. We therefore limit our sample of the FDIC-assisted acquisitions to relatively more competitive auctions. We consider only the auctions where at least 3 bidders attend. This reduces the sample of the FDIC-assisted acquisitions from 214 to 117.

The coefficients and marginal effects at the mean are presented in columns (3) and (4), respectively. The results show that imposing this restriction increases the significance level of all indicators of Acquirer Financials other than Acquirer Tier 1 Ratio, which remains insignificant. The probability of success in the FDIC auctions increases with the increase in Acquirer Relative

\footnotetext{
${ }^{28}$ In two unreported regression estimations, we use Acquirer Labor Cost and Acquirer Other Expenses instead of Acquirer Inefficiency and find similar results: The probability of success in the FDIC auctions is positively associated with Acquirer Labor Cost and Acquirer Other Expenses. We also use Acquirer Employees and Acquirer Wage instead of Acquirer Inefficiency in our model and find that both have insignificant coefficients.
} 
Size, Acquirer Non-Performing Loans, Acquirer Inefficiency, Acquirer Non-Interest Income and Acquirer Age and obtaining a better CAMELS score. The result shows that, even in more competitive auctions, an increase in the inefficiency of acquirers predicts a higher probability of acquiring a failed bank. As reported in column (4), the marginal effects at the mean of Acquirer Inefficiency is tripled in this specification.

\section{[TABLE VI]}

\subsection{Financial Strength and Probability of Multiple Acquisitions}

Our data show that there are acquirers that took over multiple targets during our study period. We expect that the acquirers of multiple failed banks must be stronger than other acquirers to win the auctions repeatedly. However, the claim of Igan et al. (2017) - that banks that engage in lobbying have a higher chance to win the FDIC auctions - casts doubt on this expectation.

In this sub-section, we examine whether such banks are financially stronger than those that take over only one bank throughout our sample period. We define a dummy variable that takes the value one when an acquirer takes over more than one target, and zero otherwise. We use this dummy variable as the dependent variable in Equation (2) and estimate our model (with logit regressions) for the FDIC-assisted acquisitions only. ${ }^{29}$

Table VII illustrates the results. In columns (1) and (2), the dependent variable is the probability of multiple takeovers during the study period, i.e. 2007:Q1-2016:Q3 (excluding multiple takeovers in the same quarter). The results show that having a larger Relative Size increases the probability of acquiring multiple failed banks. Marginal effects at the mean reported in column (2) show that a one percent increase from the mean in Acquirer Relative Size is

\footnotetext{
${ }^{29} \mathrm{We}$ do not estimate the model for the sample of commercial banks that acquire multiple healthy banks due to the lack of adequate data. For BHCs that acquire multiple healthy banks, the Wald test rejects the statistical significance of the model. Hence, we do not report the results in the paper.
} 
associated with a $0.6 \%$ increase in the probability of acquiring multiple failed banks. We find no significant relationship between Acquirer Tier 1 Ratio and the dependent variable. A higher probability of taking over multiple failed banks is associated with a higher Acquirer NonPerforming Loans. The probability of acquiring multiple failed banks increases by $3.4 \%$ with a one percent increase from the mean in Acquirer Non-performing Loans. The economic significance is meaningful, because the average Non-performing Loans for acquirers of failed banks in our sample is $3.4 \%$. The significantly positive coefficient of Acquirer Non-performing Loans can be due to previous acquisitions of failed banks.

Acquirer Inefficiency, ${ }^{30}$ Acquirer CAMELS Score, and Acquirer Core Deposits depict insignificant coefficients. However, we find that the probability increases with an increase in Acquirer Net Interest Margin and Acquirer Non-Interest Income. An increase in Acquirer Age is associated with a lower probability of acquiring multiple failed banks. Overall, the result shows that commercial banks that acquire multiple failed banks are not financially stronger than other acquirers.

In columns (3) and (4), the dependent variable is a dummy variable that takes the value of one when the acquirer takes over more than one target in a given quarter, and zero otherwise. The sample is restricted to the FDIC-assisted acquisitions, because in our sample there are only 3 observations on multiple acquisitions of healthy targets in a given quarter by a BHC.

The results show that acquirers with a higher Tier 1 Ratio have a higher probability of acquiring multiple failed banks in a given quarter, which is in line with our expectation because better capitalized banks have a larger capacity to purchase assets and assume core deposits of failed

\footnotetext{
${ }^{30}$ In two unreported regression estimations, we use Acquirer Labor Cost and Acquirer Other Expenses instead of Acquirer Inefficiency and find that both have insignificant coefficients. We also use Acquirer Employees and Acquirer Wage instead of Acquirer Inefficiency in our model and find similar results.
} 
banks. This finding also supports the prediction of Granja et al. (2017) that higher capitalization increases the probability of wining the FDIC auctions. Nevertheless, the relationship is not economically substantial, as a one percent increase from the mean of Acquirer Tier 1 Ratio -which is $14.82 \%$ in our sample -- predicts a $1 \%$ increase in the probability of acquiring multiple failed banks in the same quarter. A one percent increase approximately equals $7 \%$ of the mean Tier 1 Ratio.

\section{[TABLE VII]}

\section{Concluding Remarks}

In the U.S., the FDIC resolves failed banks by selling them to healthy financial institutions. The sale is conducted in the form of an auction that is open to eligible acquirers that are invited by the FDIC. There are two major concerns regarding the resolution process: a) whether failed banks are sold at a fair price, $b$ ) whether the FDIC sells failed banks to the right acquirers.

The FDIC attempts to address these two concerns by setting certain criteria for eligible bidders, and by assessing the bids and choosing the one that is the least costly to the deposit insurance fund. In this paper, we extend the literature on allocation of failed banks by examining the factors that could explain the acquisition price by considering a framework where the purchase and assumption of failed banks in the FDIC auctions are compared with the takeover of healthy banks.

We build a sample of U.S. commercial banks that were acquired through the FDIC's P\&A deals and a group of banks that were purchased without the FDIC's assistance. Our sample consists of 234 banks that were acquired under P\&A transactions and 386 banks that were acquired through non-assisted deals between 2007:Q1 and 2016:Q3. The descriptive statistics show that on average, 
bidders paid a $0.35 \%$ premium for assuming deposits of failed banks and received on average a $13.68 \%$ discount for purchase of assets of failed banks.

The results indicate that failed banks with more branches are sold, on average, at higher prices, whereas, in principle, the FDIC is known to charge a premium from acquirers merely for assuming core deposits. Our results reveal that the premium for the franchise value of failed banks is embedded in the size of their branch networks rather than in their core deposits per se. The prices also increase with the number of bidders that attend the auctions organized by the FDIC. Our investigation also shows that acquirers with more employees pay lower premiums to assume the core deposits of failed banks. This result holds even when we control for the impact of competition on the acquisition prices. (On possible implication of our findings is that the FDIC may favor acquirers with more employees because they are expected to better serve the depositors of the failed banks.)

We then examine inefficiency and financial strength of acquirers of failed banks vis-à-vis acquirers of healthy banks. The results show that an increase in inefficiency and non-performing loans of acquirers is associated with a higher probability of acquiring failed banks rather than healthy banks. The findings persist even when we limit the FDIC-assisted deals to those that are more competitive.

Finally, we explore whether the acquirers of multiple targets are financially stronger than those that acquired only one target during our study period. We find that the acquirers of failed banks -- contrary to the acquirers of healthy targets -- have even higher non-performing loans. The results imply that even though CAMELS scores might play a useful role in ranking potential bidders the scores cannot carry sufficient information as to the bidders' inefficiency and loan quality. 
This has important implications as it shows that to sell failed banks at a higher price, not only competition must be increased in the auctions but also that the criteria for inviting eligible bidders might need to be revisited. Moreover, the findings suggest that acquirers that cope with larger amounts of non-performing loans prefer failed banks to healthy banks for takeovers, possibly because they have better expertise in managing troubled assets or because such deals are more accessible. 


\section{References}

Acharya, V.V. and Yorulmazer T. (2007) Too many to fail - An analysis of time-inconsistency in bank closure policies, Journal of Financial Intermediation 16(1): 1-31.

Bertin, W., Ghazanfari, F. and Torabzadeh, K. (1989) Failed bank acquisitions and successful bidders' returns, Financial Management 18: 93-100.

Blinder, A.S. (1973) Wage discrimination: Reduced form and structural estimates. Journal of Human Resources 8: 436-455.

Carlson, M. (2004) Are branch bank better survivors? Evidence from the depression era, Economic Inquiry 42(1): 111-126.

Chu, K.H. (2010) Bank mergers, branch networks and economic growth: Theory and evidence from Canada, 1889-1926, Journal of Macroeconomics 32: 265-283.

Cochran, B., Rose, L. and Fraser, D. (1995) A market evaluation of FDIC assisted transactions, Journal of Banking \& Finance 19: 245-259.

Cole, R.A. and White, L.J. (2012) Déjà vu all over again: The causes of U.S. commercial bank failures this time around, Journal of Financial Services Research 42: 5-29.

Degryse, H. and Ongena, S. (2005) Distance, lending relationships, and competition, Journal of Finance 60(1): 231-266.

Demsetz, R.S., Saidenberg, M.R. and Strahan, P.E. (1996) Banks with something to lose: The disciplinary role of franchise value, Economic Policy Review 2(2): 1-14.

Ergungor, E. (2005) The profitability of bank-borrower relationships, Journal of Financial Intermediation 14(4): 485-512.

Gilje, E.P., Loutskina, E. and Strahan, P.E. (2016) Exporting liquidity: Branch banking and financial integration, The Journal of Finance 71(3): 1159-1183.

Granja, J., Matvos, G. and Seru, A. (2017) Selling failed banks, The Journal of Finance 72(4): 1723-1784.

Hannan, T.H. and Prager, R.A. (2004) The competitive implications of multimarket bank branching, Journal of Banking \& Finance 28: 1889-1914.

Hirtle, B.J. and Stiroh, K.J. (2007) The return to retail and the performance of US banks, Journal of Banking \& Finance 31: 1101-1133.

Igan, D., Lambert, T., Wagner, W. and Zhang, Q. (2017) Wining connections? Special interests and the sale of failed banks, IMF Working Paper WP/17/262.

James, C. and Wier, P. (1987) Returns to acquirers and competition in the acquisition market: The case of banking, Journal of Political Economy 95: 355-370.

Jann, B. (2008) The Blinder-Oaxaca decomposition for linear regression models. The Stata Journal 8(4): 453-479.

Jayaratne, J. and Strahan, P.E. (1996) The finance-growth nexus: Evidence from bank branch deregulation, Quarterly Journal of Economics 111(3): 639-670. 
LaPlante, A.E. and Paradi, J.C. (2015) Evaluation of bank branch growth potential using data envelopment analysis, Omega 52: 33-41.

Liang, H.Y., Ching, Y.P. and Chan, K.C. (2013) Enhancing bank performance through branches or representative offices? Evidence from European banks, International Business Review 22: 495-508.

Loveland, R. (2012) Does it pay to win an FDIC auction?, Working Paper, July, 2012.

Oaxaca, R. (1973) Male-female wage differentials in urban labor markets, International Economic Review 14: 693-709.

Petersen, M.A. and Rajan, R.G. (1995) The effect of credit market competition on lending relationships, Quarterly Journal of Economics 110: 406-443.

Pettway, R. and Thrifts, J. (1985) Do banks overbid when acquiring failed banks? Financial Management 14: 5-15.

Ramírez, C.D. (2003) Did branch banking restrictions increase bank failures? Evidence from Virginia and West Virginia in the late 1920s, Journal of Economics and Business 55: 331352.

Resolutions Handbook (2014), https://www.fdic.gov/about/freedom/drr_handbook.pdf.

Salop, S.C. (1979) Monopolistic competition with outside goods, The Bell Journal of Economics 10(1): 141-156.

Santikian, L. (2014) The ties that bind: Bank relationships and small business lending, Journal of Financial Intermediation 23(2): 177-213.

Staikouras, S.K. (2006) Business opportunities and market realities in financial conglomerates, The Geneva Papers on Risk and Insurance, Issues and Practice 31: 124-148.

Williams, B. (2002) The defensive expansion approach to multinational banking: Evidence to date, Financial Markets, Institutions \& Instruments 11(2): 127-203.

Zhang, H. (1997) Repeated acquirers in FDIC-assisted bank acquisitions, Journal of Banking \& Finance 10: 1419-1430. 


\section{Table I. Variable Description}

This table presents description of variables used in this study.

\begin{tabular}{|c|c|}
\hline Variables & Description \\
\hline Assisted Acquisition & A dummy variable equals to one for the FDIC-assisted acquisitions, and zero otherwise. \\
\hline \multicolumn{2}{|l|}{ Deal Characteristics } \\
\hline Price Asset Ratio & $\begin{array}{l}\text { Price Asset Ratio }=100 \times \text { [value of acquired banks] / [total assets of acquired banks]. The numerator is the } \\
\text { price paid by the acquirer at the completion date of acquisition, for the non-assisted deals. For the FDIC- } \\
\text { assisted transactions, the numerator is the summation of the discount received for the purchase of total assets } \\
\text { and the premium paid for assumption of deposits. The discount takes a negative value, but the premium is a } \\
\text { positive number. For the deals with a loss-share agreement, we add the value of the loss-share agreement to } \\
\text { the numerator with a negative sign. The value of loss-share agreement is the product of the percentage of } \\
\text { the loss share agreement (tranche), loss share amount and probability of loss. The first two items are obtained } \\
\text { from the FDIC website and the last item is estimated by calculating the average net charge-off on gross loans } \\
\text { ratio of failed banks over their last four quarters of operation. }\end{array}$ \\
\hline Deposit Premium & $\begin{array}{l}\text { The premium paid by an acquirer for assumption of a failed bank's core deposits divided by core deposits } \\
\text { of the failed bank. }\end{array}$ \\
\hline Asset Discount & $\begin{array}{l}\text { The discount received by an acquirer for purchase of a failed bank's total assets divided by total assets of } \\
\text { the failed bank. }\end{array}$ \\
\hline Loss Share Value & $\begin{array}{l}\text { The expected value of the FDIC's commitment to share some of the future losses of the acquiring bank of a } \\
\text { failed bank. The value of loss-share agreement is the product of the percentage of the loss share agreement } \\
\text { (tranche), loss share amount and probability of loss. The first two items are obtained from the FDIC website } \\
\text { and the last item is estimated by calculating the average net charge-off on gross loans ratio of failed banks } \\
\text { over their last four quarters of operation. }\end{array}$ \\
\hline Number Bidders & The number of bidders who attend the auction for selling a failed bank. \\
\hline Same County & $\begin{array}{l}\text { A dummy variable that takes the value of one when both acquirer and target are in the same county, and zero } \\
\text { otherwise. }\end{array}$ \\
\hline \multicolumn{2}{|l|}{ Acquirers Characteristics } \\
\hline Acquirer Relative Size & The ratio of total assets of an acquirer to total assets of the target. \\
\hline Acquirer Tier 1 Ratio & $\begin{array}{l}\text { Tier } 1 \text { risk-based capital ratio of an acquirer. The ratio equals tier } 1 \text { capital divided by total risk-weighted } \\
\text { assets. }\end{array}$ \\
\hline $\begin{array}{l}\text { Acquirer Non-Performing } \\
\text { Loans }\end{array}$ & $\begin{array}{l}\text { The ratio of non-performing loans of an acquirer to its total loans. Non-performing loans consist of } \\
\text { nonaccrual loans and loans which are past due for } 90 \text { days or more and still accruing. }\end{array}$ \\
\hline Acquirer Inefficiency & $\begin{array}{l}\text { The ratio of total non-interest expense of an acquirer to its total operating revenue. Total non-interest expense } \\
\text { includes salary and benefits, occupancy and equipment, and other non-interest expense. }\end{array}$ \\
\hline Acquirer Labor Cost & The ratio of employees' salaries and benefits of an acquirer to its total operating revenue. \\
\hline Acquirer Other Expenses & $\begin{array}{l}\text { The ratio of occupancy and equipment expenses and other non-interest expenses of an acquirer to its total } \\
\text { operating revenue. }\end{array}$ \\
\hline Acquirer Employees & The ratio of number of full-time employees of an acquirer to its total operating revenue. \\
\hline Acquirer Wage & The ratio of employees' salaries and benefits of an acquirer to its total number of full-time employees. \\
\hline Acquirer CAMELS Score & $\begin{array}{l}\text { The CAMELS stands for Capital Adequacy, Assets, Management Capability, Earnings, Liquidity and } \\
\text { sensitivity. Eligible acquirers must hold acceptable CAMELS ratings. }\end{array}$ \\
\hline Acquirer Core Deposits & $\begin{array}{l}\text { The share in total liabilities of core deposits of an acquirer. Core deposits, in the Uniform Bank Performance } \\
\text { Report (UBPR) and until March } 31,2011 \text {, are defined as the sum of demand deposits, all NOW and } \\
\text { automatic transfer service (ATS) accounts, money market deposit accounts (MMDAs), other savings } \\
\text { deposits, and time deposits under } \$ 100,000 \text {. }\end{array}$ \\
\hline Acquirer Net Interest Margin & Interest income minus interest expense of an acquirer divided by its total earning assets. \\
\hline Acquirer Non-Interest Income & The income from non-interest activities of an acquirer divided by its total operating income. \\
\hline Acquirer Age & The difference between the current year and the year of establishment of an acquirer. \\
\hline Acquirer Branch & The number of branches of an acquirer. \\
\hline Acquisition Number & The number of acquisitions of either healthy or failed banks by one acquirer during the study period. \\
\hline Acquisition Quarter & The number of acquisitions of either healthy or failed banks by one acquirer in each quarter. \\
\hline \multicolumn{2}{|l|}{ Targets Characteristics } \\
\hline Core Deposits & Share of core deposits of a target in its total liabilities. \\
\hline
\end{tabular}




\begin{tabular}{ll} 
Non-Performing Loans & The ratio of non-performing loans of a target to its total loans. \\
Number Branch & The number of branches of a target. \\
\hline Inefficiency & The inefficiency of a target calculated as the ratio of total non-interest expense to total assets. \\
\hline Commercial Mortgage & The share of commercial mortgage of a target in its total loans. \\
\hline $\begin{array}{l}\text { Market Share } \\
\text { Equity Asset Ratio }\end{array}$ & The market share of a target in a given state. The market share is calculated based on total assets. \\
\hline Non-Interest Income & The equity capital to asset ratio of a target. \\
\hline Age & The income from non-interest activities of a target divided by its total operating income. \\
\hline
\end{tabular}




\section{Table II. Descriptive Statistics}

\section{Panel A. Targets}

This panel presents general descriptive statistics and deals specifications for targets of FDIC-assisted and non-assisted acquisitions over 2007:Q1 and 2016:Q3 period.

\begin{tabular}{|c|c|c|c|c|c|c|c|c|c|c|c|c|}
\hline & \multicolumn{7}{|c|}{ Targets of Non-Assisted Takeovers } & \multicolumn{5}{|c|}{ Targets of Assisted Takeovers } \\
\hline & Variable & $\mathrm{N}$ & Mean & SD & Min & Max & $\mathrm{N}$ & Mean & SD & Min & Max & T-Stat \\
\hline \multirow{10}{*}{ 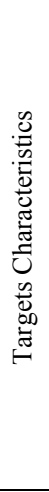 } & Total Assets & 386 & 478 & 1,549 & 7 & 11,698 & 234 & 424 & 791 & 20 & 5,681 & 0.49 \\
\hline & Core Deposits & 386 & 83.23 & 13 & 40.72 & 99.93 & 234 & 75.88 & 19.79 & 15.59 & 99.6 & $5.58 * * *$ \\
\hline & Number Branch & 386 & 7.47 & 18.47 & 1.00 & 127.00 & 234 & 5.92 & 8.35 & 1.00 & 55.00 & 1.21 \\
\hline & Non-performing Loans & 386 & 2.94 & 4.1 & 0 & 20.65 & 234 & 18.61 & 8.67 & 2.05 & 44.78 & $-30 * * *$ \\
\hline & Inefficiency & 386 & 0.93 & 0.45 & 0.09 & 3.11 & 234 & 1.17 & 0.5 & 0.38 & 3.4 & $-6.09 * * *$ \\
\hline & Commercial Mortgage & 386 & 32.88 & 18.75 & 0.00 & 73.97 & 234 & 37.44 & 14.62 & 7.83 & 73.46 & $-3.18 * * *$ \\
\hline & Market Share & 386 & 0.3 & 1.11 & 0.00 & 8.67 & 234 & 0.19 & 0.39 & 0 & 2.45 & 1.43 \\
\hline & Equity Asset Ratio & 386 & 10.97 & 4.23 & 2.88 & 27.31 & 234 & 1.24 & 2.02 & -4.24 & 7.84 & $33 * * *$ \\
\hline & Non-Interest Income & 386 & 0.16 & 0.29 & -0.54 & 2.25 & 234 & -0.01 & 0.35 & -1.37 & 0.91 & $6.59 * * *$ \\
\hline & Age & 386 & 42.87 & 42.88 & 2.53 & 140.74 & 234 & 33.45 & 36.6 & 3.69 & 147.74 & $2.80 * * *$ \\
\hline \multirow{6}{*}{ 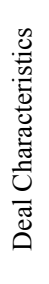 } & Price Asset Ratio & 386 & 14.25 & 7.22 & 0.52 & 37.53 & 234 & -14.9 & 8.92 & -43.55 & 0.89 & $44 * * *$ \\
\hline & Deposit Premium & & & & & & 234 & 0.35 & 0.64 & 0 & 3.61 & \\
\hline & Asset Discount & & & & & & 234 & -13.68 & 8.92 & -43.55 & 0.14 & \\
\hline & Loss Share Value & & & & & & 119 & -2.93 & 1.65 & -7.93 & -0.44 & \\
\hline & Number Bidders & & & & & & 230 & 2.9 & 1.67 & 1 & 8 & \\
\hline & Same County & 386 & 0.10 & 0.29 & 0.00 & 1.00 & 234 & 0.09 & 0.29 & 0.00 & 1.00 & 0.25 \\
\hline
\end{tabular}

$\dagger$ T-Stat. of mean equality test between FDIC-assisted and non-assisted acquisitions. $* * *, * *$ and $*$ indicate significance at $1 \%, 5 \%$ and $10 \%$ respectively. See Table I for variable definitions. 


\section{Panel B. Acquirers}

This panel presents general descriptive statistics for acquirers of FDIC-assisted and non-assisted deals over 2007:Q1 and 2016:Q3 period. Acquirers of non-assisted acquisitions are classified into two groups of banks: commercial banks and BHCs, whereas failed banks are sold merely to commercial banks.

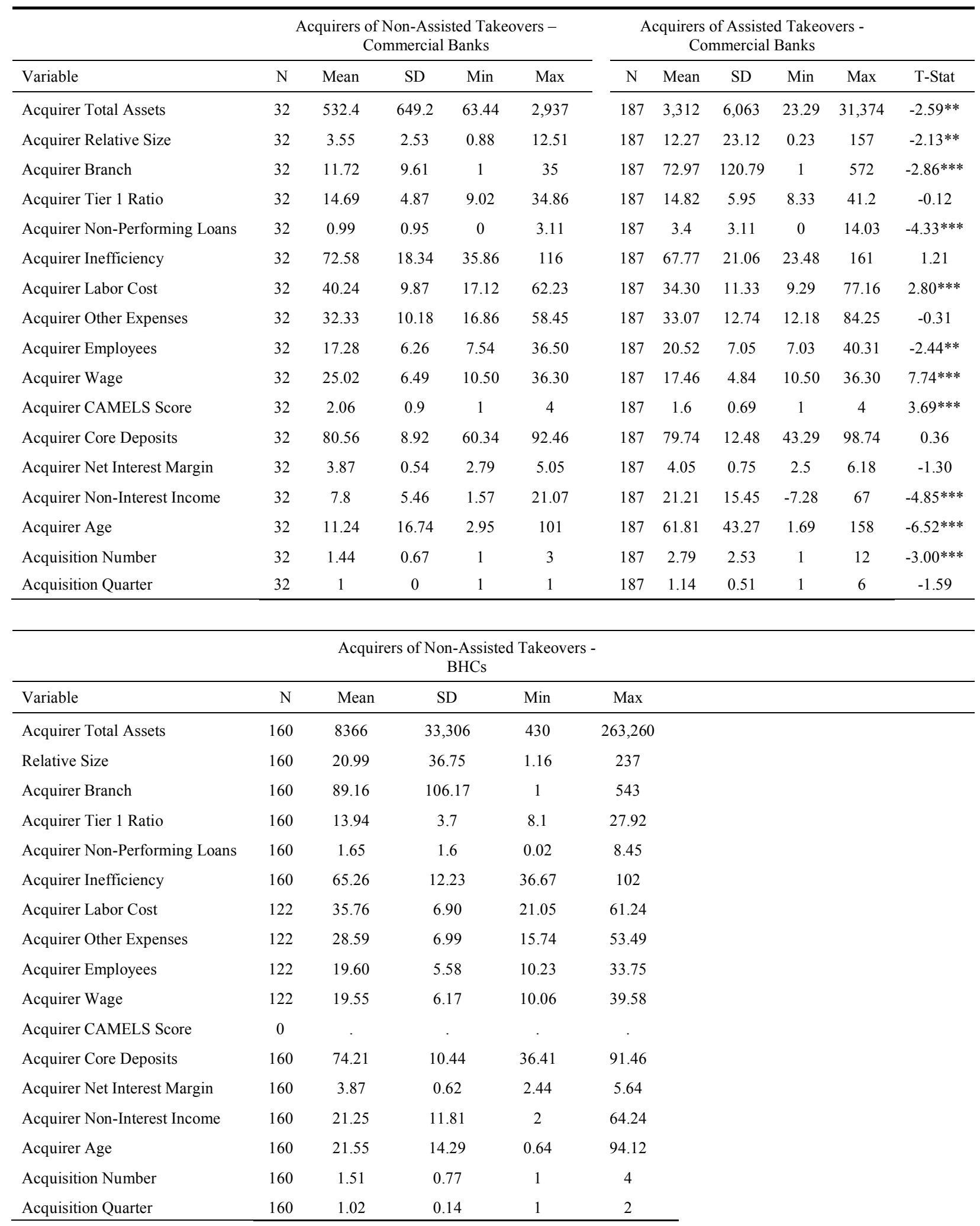


$\dagger$ T-Stat. of mean equality test between FDIC-assisted and non-assisted acquisitions. ***,** and * indicate significance at $1 \%, 5 \%$ and $10 \%$ respectively. See Table I for variable definitions. 


\section{Table III. Franchise Value Model - The Role of Acquirer Inefficiency}

Panel A reports estimation of preferred specification of Equation (1) using OLS techniques and our pooled cross-section samples of assisted and non-assisted acquisitions during 2007:Q1-20176:Q3 period. In column (1), we estimate our model using data on non-assisted acquisitions. Column (2) reports estimation result using data on assisted acquisitions. Column (3) presents estimation for non-assisted acquisitions, after inclusion of three financial indicators of acquirers, i.e. Acquirer Tier 1 Ratio, Acquirer NonPerforming Loans and Acquirer Inefficiency. In columns (4), (5) \& (6), we examine assisted acquisitions and use Price Asset Ratio, Asset Discount \& Loss Share Value and Deposit Premium as the dependent variable, respectively.

Panel B exhibits the Blinder-Oaxaca decomposition analysis. The analysis is conducted based on the estimations of preferred specification of Equation (1) for failed banks and healthy banks acquisitions, the results of them are presented in columns (1) and (2) of panel A. The first part of the table illustrates the mean predictions of Price Asset Ratio of healthy targets and failed banks and their differences. The second part of the table exhibits the decomposition of the gap between Price Asset Ratio of failed banks and healthy targets. The gap between the two groups is divided into three parts. The first part shows the man increase in the Price Asset Ratio of failed banks if they had the same characteristics as healthy targets. The second part reflects the change in failed banks' Price Asset Ratio when we use the coefficients of healthy target regression estimation to the failed banks characteristics. The third part shows the interaction term, which captures the simultaneous impact of differences in endowments and coefficients.

\begin{tabular}{|c|c|c|c|c|c|c|}
\hline \multicolumn{7}{|l|}{ Panel A. Regression Estimation } \\
\hline & (1) & (2) & (3) & (4) & (5) & (6) \\
\hline & $\begin{array}{c}\text { Non-assisted } \\
\text { Acquisition }\end{array}$ & $\begin{array}{c}\text { Assisted } \\
\text { Acquisition }\end{array}$ & $\begin{array}{l}\text { Non-assisted } \\
\text { Acquisition }\end{array}$ & & $\begin{array}{c}\text { Assisted } \\
\text { Acquisition }\end{array}$ & \\
\hline Variables & $\begin{array}{c}\text { Price Asset } \\
\text { Ratio }\end{array}$ & $\begin{array}{c}\text { Price Asset } \\
\text { Ratio }\end{array}$ & $\begin{array}{c}\text { Price Asset } \\
\text { Ratio }\end{array}$ & $\begin{array}{l}\text { Price Asset } \\
\text { Ratio }\end{array}$ & $\begin{array}{l}\text { Asset Discount \& } \\
\text { Loss Share Value }\end{array}$ & $\begin{array}{c}\text { Deposit } \\
\text { Premium }\end{array}$ \\
\hline Core Deposits & $\begin{array}{c}0.056^{* * *} \\
(0.028)\end{array}$ & $\begin{array}{c}0.003 \\
(0.040)\end{array}$ & $\begin{array}{c}0.011 \\
(0.035)\end{array}$ & $\begin{array}{c}0.010 \\
(0.041)\end{array}$ & $\begin{array}{c}0.000 \\
(0.040)\end{array}$ & $\begin{array}{l}0.007 * \\
(0.004)\end{array}$ \\
\hline Log_Branch & $\begin{array}{c}0.079 \\
(0.327)\end{array}$ & $\begin{array}{l}1.558^{* *} \\
(0.692)\end{array}$ & $\begin{array}{c}0.043 \\
(0.349)\end{array}$ & $\begin{array}{l}1.624 * * \\
(0.802)\end{array}$ & $\begin{array}{l}1.664^{* *} \\
(0.794)\end{array}$ & $\begin{array}{l}-0.020 \\
(0.048)\end{array}$ \\
\hline Non-performing Loans & $\begin{array}{c}-0.655^{* * * *} \\
(0.078)\end{array}$ & $\begin{array}{l}-0.058 \\
(0.084)\end{array}$ & $\begin{array}{c}-0.589 * * * \\
(0.082)\end{array}$ & $\begin{array}{l}-0.073 \\
(0.087)\end{array}$ & $\begin{array}{l}-0.073 \\
(0.086)\end{array}$ & $\begin{array}{l}-0.001 \\
(0.005)\end{array}$ \\
\hline Inefficiency & $\begin{array}{c}0.498 \\
(0.857)\end{array}$ & $\begin{array}{l}-3.066^{*} \\
(1.575)\end{array}$ & $\begin{array}{c}-0.697 \\
(1.065)\end{array}$ & $\begin{array}{l}-2.971^{*} \\
(1.657)\end{array}$ & $\begin{array}{l}-2.965^{*} \\
(1.627)\end{array}$ & $\begin{array}{l}-0.041 \\
(0.096)\end{array}$ \\
\hline Commercial Mortgage & $\begin{array}{l}-0.012 \\
(0.018)\end{array}$ & $\begin{array}{l}-0.060 \\
(0.053)\end{array}$ & $\begin{array}{c}0.012 \\
(0.025)\end{array}$ & $\begin{array}{l}-0.053 \\
(0.055)\end{array}$ & $\begin{array}{l}-0.050 \\
(0.054)\end{array}$ & $\begin{array}{l}-0.002 \\
(0.003)\end{array}$ \\
\hline Market Share & $\begin{array}{c}0.582 * * * \\
(0.201)\end{array}$ & $\begin{array}{l}1.175 \\
(1.084)\end{array}$ & $\begin{array}{l}0.514^{*} \\
(0.272)\end{array}$ & $\begin{array}{c}0.658 \\
(1.425)\end{array}$ & $\begin{array}{c}0.442 \\
(1.421)\end{array}$ & $\begin{array}{l}0.275^{* *} \\
(0.133)\end{array}$ \\
\hline Size & $\begin{array}{l}-0.626 \\
(0.493)\end{array}$ & $\begin{array}{c}0.351 \\
(1.028)\end{array}$ & $\begin{array}{c}0.391 \\
(0.850)\end{array}$ & $\begin{array}{c}0.188 \\
(1.099)\end{array}$ & $\begin{array}{c}0.215 \\
(1.076)\end{array}$ & $\begin{array}{l}-0.006 \\
(0.088)\end{array}$ \\
\hline Acquirer Tier 1 Ratio & & & $\begin{array}{l}-0.033 \\
(0.090)\end{array}$ & $\begin{array}{l}-0.056 \\
(0.077)\end{array}$ & $\begin{array}{l}-0.068 \\
(0.077)\end{array}$ & $\begin{array}{l}0.014 * * \\
(0.006)\end{array}$ \\
\hline Acquirer Non-performing Loans & & & $\begin{array}{l}-0.405 \\
(0.263)\end{array}$ & $\begin{array}{c}0.203 \\
(0.147)\end{array}$ & $\begin{array}{c}0.210 \\
(0.148)\end{array}$ & $\begin{array}{l}-0.007 \\
(0.010)\end{array}$ \\
\hline Acquirer Inefficiency & & & $\begin{array}{c}-0.101^{* * * *} \\
(0.030)\end{array}$ & $\begin{array}{c}-0.057 * * \\
(0.026)\end{array}$ & $\begin{array}{c}-0.054 * * \\
(0.026)\end{array}$ & $\begin{array}{c}-0.005 * * * \\
(0.002)\end{array}$ \\
\hline Year 2008 & $\begin{array}{c}-4.730 * * * \\
(1.537)\end{array}$ & $\begin{array}{l}6.793 * * \\
(2.687)\end{array}$ & $\begin{array}{l}-3.579 \\
(3.661)\end{array}$ & $\begin{array}{c}4.807 \\
(2.998)\end{array}$ & $\begin{array}{c}4.175 \\
(2.761)\end{array}$ & $\begin{array}{c}0.056 \\
(0.239)\end{array}$ \\
\hline Year 2009 & $\begin{array}{c}-7.146 * * * \\
(1.878)\end{array}$ & $\begin{array}{c}-6.559 * * * \\
(2.282)\end{array}$ & $\begin{array}{l}-6.096^{*} \\
(3.353)\end{array}$ & $\begin{array}{c}-7.150 * * * \\
(2.488)\end{array}$ & $\begin{array}{c}-7.595 * * * \\
(2.408)\end{array}$ & $\begin{array}{c}0.485^{* *} \\
(0.188)\end{array}$ \\
\hline Year 2010 & $\begin{array}{c}-7.997 * * * \\
(1.466)\end{array}$ & $\begin{array}{c}-5.807 * * * \\
(1.811)\end{array}$ & $\begin{array}{c}-10.552 * * * \\
(2.644)\end{array}$ & $\begin{array}{c}-6.699 * * * \\
(1.943)\end{array}$ & $\begin{array}{c}-6.832 * * * \\
(1.912)\end{array}$ & $\begin{array}{c}0.152 \\
(0.142)\end{array}$ \\
\hline Year 2011 & $\begin{array}{c}-8.113 * * * \\
(1.327)\end{array}$ & $\begin{array}{c}-9.512 * * * \\
(2.238)\end{array}$ & $\begin{array}{c}-6.914 * * * \\
(2.395)\end{array}$ & $\begin{array}{c}-10.827 * * * \\
(2.406)\end{array}$ & $\begin{array}{c}-10.777 * * * \\
(2.383)\end{array}$ & $\begin{array}{l}-0.064 \\
(0.131)\end{array}$ \\
\hline Year 2012 & $\begin{array}{c}-9.099^{* * *} \\
(1.252)\end{array}$ & $\begin{array}{c}-8.311 * * * \\
(2.413)\end{array}$ & $\begin{array}{c}-8.784 * * * \\
(1.923)\end{array}$ & $\begin{array}{c}-9.361^{* * *} \\
(2.412)\end{array}$ & $\begin{array}{c}-9.335^{* * *} \\
(2.401)\end{array}$ & $\begin{array}{c}-0.019 \\
(0.183)\end{array}$ \\
\hline Year 2013 & $\begin{array}{c}-7.620 * * * \\
(1.259)\end{array}$ & $\begin{array}{c}1.003 \\
(2.013)\end{array}$ & $\begin{array}{c}-8.236 * * * \\
(1.817)\end{array}$ & $\begin{array}{c}1.431 \\
(1.997)\end{array}$ & $\begin{array}{c}1.331 \\
(1.914)\end{array}$ & $\begin{array}{c}0.153 \\
(0.197)\end{array}$ \\
\hline Year 2014 & $\begin{array}{c}-8.409 * * * \\
(1.195)\end{array}$ & $\begin{array}{l}-6.499 \\
(5.262)\end{array}$ & $\begin{array}{c}-7.884 * * * \\
(1.806)\end{array}$ & $\begin{array}{l}-7.184 \\
(5.543)\end{array}$ & $\begin{array}{l}-7.254 \\
(5.588)\end{array}$ & $\begin{array}{c}0.121 \\
(0.292)\end{array}$ \\
\hline Year 2015 & $\begin{array}{c}-5.989 * * * \\
(1.158)\end{array}$ & $\begin{array}{l}-0.835 \\
(2.514)\end{array}$ & $\begin{array}{c}-7.132 * * * \\
(1.696)\end{array}$ & $\begin{array}{c}-3.978 * * \\
(1.728)\end{array}$ & $\begin{array}{c}-3.846^{* *} \\
(1.677)\end{array}$ & $\begin{array}{l}-0.118 \\
(0.158)\end{array}$ \\
\hline Year 2016 & $\begin{array}{c}-6.330 * * * \\
(1.336)\end{array}$ & $\begin{array}{c}0.001 \\
(1.336)\end{array}$ & $\begin{array}{c}-8.148^{* * *} \\
(1.798)\end{array}$ & $\begin{array}{l}-0.550 \\
(1.385)\end{array}$ & $\begin{array}{c}-0.298 \\
(1.343)\end{array}$ & $\begin{array}{c}-0.226^{*} \\
(0.122)\end{array}$ \\
\hline Constant & $\begin{array}{c}17.254 * * * \\
(2.658)\end{array}$ & $\begin{array}{l}-3.899 \\
(4.769)\end{array}$ & $\begin{array}{c}29.215^{* * *} \\
(4.098)\end{array}$ & $\begin{array}{c}0.342 \\
(5.482)\end{array}$ & $\begin{array}{c}0.766 \\
(5.383)\end{array}$ & $\begin{array}{l}-0.073 \\
(0.407)\end{array}$ \\
\hline
\end{tabular}


195

0.517

214

214

0.214

214

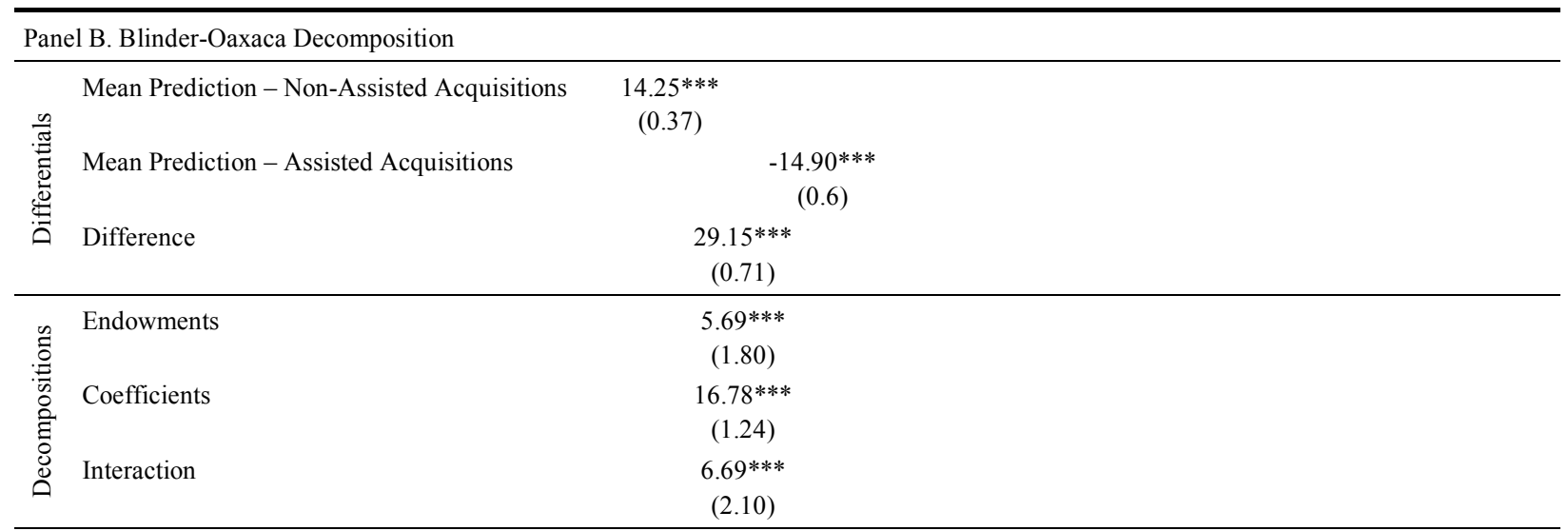

See table I for variable definitions. Robust standard errors in parentheses. $* * *, * *$ and $*$ indicate significance at $1 \%, 5 \%$ and $10 \%$, respectively. 


\section{Table IV. Franchise Value Model - Acquirer's Inefficiency Decomposition}

This table reports estimation of preferred specification of Equation (1) after including Acquirer Tier 1 Ratio and Acquirer NonPerforming Loans. We use OLS techniques and our pooled cross-section sample of assisted acquisitions during 2007:Q1-20176:Q3 period. Year fixed effects are controlled for in the model, and the F-test shows that the coefficients are jointly significant; nevertheless, for brevity, the coefficients are not reported in the table.

We use Price Asset Ratio as the dependent variable in columns (1) to (4). Asset Discount \& Loss Share Value is our dependent variable in column (5). In columns (6) and (7), the dependent variable is Deposit Premium. Instead of Acquirer Inefficiency, we include Acquirer Labor Cost and Acquirer Other Expenses in columns (1) and (2), Acquirer Wage in column (3), and Acquirer Employees in columns (4) to (7). Lastly, column (7) reports the estimation result when we add Acquirer Log_Branch to our model.

\begin{tabular}{|c|c|c|c|c|c|c|c|}
\hline & (1) & (2) & (3) & (4) & (5) & $(6)$ & (7) \\
\hline Variables & $\begin{array}{c}\text { Price Asset } \\
\text { Ratio }\end{array}$ & $\begin{array}{c}\text { Price Asset } \\
\text { Ratio }\end{array}$ & $\begin{array}{c}\text { Price Asset } \\
\text { Ratio }\end{array}$ & $\begin{array}{c}\text { Price Asset } \\
\text { Ratio }\end{array}$ & $\begin{array}{l}\text { Asset Discount \& } \\
\text { Loss Share Value }\end{array}$ & Deposit Premium & Deposit Premium \\
\hline Core Deposits & $\begin{array}{c}0.008 \\
(0.041)\end{array}$ & $\begin{array}{c}0.013 \\
(0.042)\end{array}$ & $\begin{array}{c}0.016 \\
(0.044)\end{array}$ & $\begin{array}{c}0.010 \\
(0.042)\end{array}$ & $\begin{array}{c}0.001 \\
(0.040)\end{array}$ & $\begin{array}{l}0.007 * \\
(0.004)\end{array}$ & $\begin{array}{l}0.007 * \\
(0.004)\end{array}$ \\
\hline Log_Branch & $\begin{array}{l}1.571 * \\
(0.811)\end{array}$ & $\begin{array}{l}1.710 * * \\
(0.803)\end{array}$ & $\begin{array}{l}1.808 * * \\
(0.812)\end{array}$ & $\begin{array}{l}1.650 * * \\
(0.823)\end{array}$ & $\begin{array}{c}1.689 * * \\
(0.815)\end{array}$ & $\begin{array}{l}-0.018 \\
(0.047)\end{array}$ & $\begin{array}{l}-0.020 \\
(0.048)\end{array}$ \\
\hline Non-performing Loans & $\begin{array}{l}-0.075 \\
(0.087)\end{array}$ & $\begin{array}{l}-0.066 \\
(0.088)\end{array}$ & $\begin{array}{l}-0.057 \\
(0.088)\end{array}$ & $\begin{array}{l}-0.071 \\
(0.086)\end{array}$ & $\begin{array}{l}-0.071 \\
(0.085)\end{array}$ & $\begin{array}{l}-0.001 \\
(0.004)\end{array}$ & $\begin{array}{l}-0.001 \\
(0.005)\end{array}$ \\
\hline Inefficiency & $\begin{array}{l}-2.904 * \\
(1.669)\end{array}$ & $\begin{array}{l}-3.070 * \\
(1.662)\end{array}$ & $\begin{array}{l}-3.123^{*} \\
(1.686)\end{array}$ & $\begin{array}{l}-3.117^{*} \\
(1.670)\end{array}$ & $\begin{array}{l}-3.101 * \\
(1.638)\end{array}$ & $\begin{array}{l}-0.054 \\
(0.100)\end{array}$ & $\begin{array}{l}-0.049 \\
(0.101)\end{array}$ \\
\hline Commercial Mortgage & $\begin{array}{l}-0.056 \\
(0.055)\end{array}$ & $\begin{array}{l}-0.052 \\
(0.055)\end{array}$ & $\begin{array}{l}-0.057 \\
(0.057)\end{array}$ & $\begin{array}{l}-0.060 \\
(0.056)\end{array}$ & $\begin{array}{l}-0.057 \\
(0.055)\end{array}$ & $\begin{array}{l}-0.003 \\
(0.003)\end{array}$ & $\begin{array}{l}-0.003 \\
(0.003)\end{array}$ \\
\hline Market Share & $\begin{array}{c}0.476 \\
(1.425)\end{array}$ & $\begin{array}{c}0.703 \\
(1.424)\end{array}$ & $\begin{array}{c}0.445 \\
(1.436)\end{array}$ & $\begin{array}{c}0.440 \\
(1.426)\end{array}$ & $\begin{array}{c}0.238 \\
(1.422)\end{array}$ & $\begin{array}{l}0.256^{*} \\
(0.135)\end{array}$ & $\begin{array}{l}0.252^{*} \\
(0.137)\end{array}$ \\
\hline Size & $\begin{array}{c}0.136 \\
(1.102)\end{array}$ & $\begin{array}{c}0.345 \\
(1.108)\end{array}$ & $\begin{array}{c}0.409 \\
(1.128)\end{array}$ & $\begin{array}{c}0.105 \\
(1.154)\end{array}$ & $\begin{array}{c}0.139 \\
(1.128)\end{array}$ & $\begin{array}{c}-0.013 \\
(0.093)\end{array}$ & $\begin{array}{l}-0.018 \\
(0.089)\end{array}$ \\
\hline Acquirer Tier 1 Ratio & $\begin{array}{l}-0.054 \\
(0.079)\end{array}$ & $\begin{array}{c}-0.074 \\
(0.076)\end{array}$ & $\begin{array}{l}-0.101 \\
(0.080)\end{array}$ & $\begin{array}{l}-0.070 \\
(0.079)\end{array}$ & $\begin{array}{l}-0.081 \\
(0.078)\end{array}$ & $\begin{array}{c}0.013 * * \\
(0.006)\end{array}$ & $\begin{array}{c}0.013 * * \\
(0.006)\end{array}$ \\
\hline Acquirer Non-performing Loans & $\begin{array}{c}0.148 \\
(0.153)\end{array}$ & $\begin{array}{c}0.243 \\
(0.149)\end{array}$ & $\begin{array}{c}0.246 \\
(0.159)\end{array}$ & $\begin{array}{c}0.218 \\
(0.146)\end{array}$ & $\begin{array}{c}0.224 \\
(0.147)\end{array}$ & $\begin{array}{c}-0.006 \\
(0.010)\end{array}$ & $\begin{array}{l}-0.006 \\
(0.011)\end{array}$ \\
\hline Acquirer Labor Cost & $\begin{array}{c}-0.117 * * \\
(0.057)\end{array}$ & & & & & & \\
\hline Acquirer Other Expenses & & $\begin{array}{l}-0.064 \\
(0.043)\end{array}$ & & & & & \\
\hline Acquirer Wage & & & $\begin{array}{c}0.041 \\
(0.160)\end{array}$ & & & & \\
\hline Acquirer Employees & & & & $\begin{array}{c}-0.146 * \\
(0.086)\end{array}$ & $\begin{array}{l}-0.136 \\
(0.085)\end{array}$ & $\begin{array}{c}-0.013 * * \\
(0.006)\end{array}$ & $\begin{array}{c}-0.013 * * \\
(0.006)\end{array}$ \\
\hline Acquirer Log_Branch & & & & & & & $\begin{array}{c}0.007 \\
(0.025)\end{array}$ \\
\hline Constant & $\begin{array}{c}-0.492 \\
(5.403)\end{array}$ & $\begin{array}{l}-1.061 \\
(5.614)\end{array}$ & $\begin{array}{l}-4.836 \\
(6.550)\end{array}$ & $\begin{array}{l}-1.700 \\
(5.298)\end{array}$ & $\begin{array}{l}-1.166 \\
(5.194)\end{array}$ & $\begin{array}{c}-0.258 \\
(0.390)\end{array}$ & $\begin{array}{c}-0.288 \\
(0.383)\end{array}$ \\
\hline Year Dummy Variables & Yes & Yes & Yes & Yes & Yes & Yes & Yes \\
\hline Observations & 214 & 214 & 214 & 214 & 214 & 214 & 214 \\
\hline R-squared & 0.214 & 0.204 & 0.198 & 0.208 & 0.211 & 0.112 & 0.112 \\
\hline
\end{tabular}

See table I for variable definitions. Robust standard errors in parentheses. $* * *, * *$ and $*$ indicate significance at $1 \%, 5 \%$ and $10 \%$, respectively. 


\section{Table V. Franchise Value Model - The Role of Competition}

This table reports estimation of preferred specification of Equation (1) after including two financial indicators of acquirers, i.e. Acquirer Tier 1 Ratio and Acquirer Non-Performing Loans, and Acquirer Employees. In addition, we include Number Bidders to our model. We use OLS techniques and our pooled cross-section sample of assisted acquisitions during 2007:Q1-20176:Q3 period. We use Price Asset Ratio, Asset Discount \& Loss Share Value and Deposit Premium as the dependent variable in columns (1), (2) and (3), respectively. Year fixed effects are controlled for in the model, and the F-test shows that the coefficients are jointly significant; nevertheless, for brevity, the coefficients are not reported in the table.

\begin{tabular}{|c|c|c|c|}
\hline & $(1)$ & (2) & (3) \\
\hline Variables & Price Asset Ratio & $\begin{array}{l}\text { Asset Discount \& } \\
\text { Loss Share Value }\end{array}$ & Deposit Premium \\
\hline Core Deposits & $\begin{array}{l}-0.008 \\
(0.039)\end{array}$ & $\begin{array}{l}-0.017 \\
(0.038)\end{array}$ & $\begin{array}{c}0.006 \\
(0.004)\end{array}$ \\
\hline Log_Branch & $\begin{array}{l}1.794 * * \\
(0.809)\end{array}$ & $\begin{array}{l}1.824^{* *} \\
(0.803)\end{array}$ & $\begin{array}{l}-0.017 \\
(0.046)\end{array}$ \\
\hline Non-performing Loans & $\begin{array}{l}-0.046 \\
(0.084)\end{array}$ & $\begin{array}{l}-0.047 \\
(0.083)\end{array}$ & $\begin{array}{l}-0.000 \\
(0.004)\end{array}$ \\
\hline Inefficiency & $\begin{array}{l}-2.516 \\
(1.634)\end{array}$ & $\begin{array}{l}-2.538 \\
(1.604)\end{array}$ & $\begin{array}{l}-0.012 \\
(0.095)\end{array}$ \\
\hline Commercial Mortgage & $\begin{array}{l}-0.056 \\
(0.052)\end{array}$ & $\begin{array}{l}-0.053 \\
(0.052)\end{array}$ & $\begin{array}{l}-0.003 \\
(0.003)\end{array}$ \\
\hline Market Share & $\begin{array}{l}-0.697 \\
(1.456)\end{array}$ & $\begin{array}{l}-0.871 \\
(1.449)\end{array}$ & $\begin{array}{l}0.231^{*} \\
(0.128)\end{array}$ \\
\hline Size & $\begin{array}{c}0.273 \\
(1.113)\end{array}$ & $\begin{array}{c}0.307 \\
(1.095)\end{array}$ & $\begin{array}{l}-0.008 \\
(0.086)\end{array}$ \\
\hline Acquirer Tier 1 Ratio & $\begin{array}{l}-0.103 \\
(0.079)\end{array}$ & $\begin{array}{l}-0.113 \\
(0.078)\end{array}$ & $\begin{array}{l}0.011^{*} \\
(0.006)\end{array}$ \\
\hline Acquirer Non-performing Loans & $\begin{array}{l}0.259^{*} \\
(0.151)\end{array}$ & $\begin{array}{l}0.258^{*} \\
(0.150)\end{array}$ & $\begin{array}{c}0.003 \\
(0.011)\end{array}$ \\
\hline Acquirer Employee & $\begin{array}{l}-0.127 \\
(0.085)\end{array}$ & $\begin{array}{l}-0.118 \\
(0.084)\end{array}$ & $\begin{array}{c}-0.012 * * \\
(0.006)\end{array}$ \\
\hline Number Bidders & $\begin{array}{c}1.604 * * * \\
(0.427)\end{array}$ & $\begin{array}{c}1.515^{* * *} \\
(0.421)\end{array}$ & $\begin{array}{c}0.110^{* * *} \\
(0.042)\end{array}$ \\
\hline Constant & $\begin{array}{c}-11.848^{* *} \\
(5.751)\end{array}$ & $\begin{array}{c}-10.786^{*} \\
(5.655)\end{array}$ & $\begin{array}{c}-0.807^{*} \\
(0.429)\end{array}$ \\
\hline Year Dummy Variables & Yes & Yes & Yes \\
\hline Observations & 210 & 210 & 210 \\
\hline R-squared & 0.249 & 0.246 & 0.175 \\
\hline
\end{tabular}

See table I for variable definitions. Robust standard errors in parentheses. $* * *, * *$ and $*$ indicate significance at $1 \%, 5 \%$ and $10 \%$, respectively. 


\section{Table VI. Financial Strength and Probability of Acquiring a Failed Bank}

This table reports estimation of Equation (2) using logit techniques. In column (1), we study our sample of acquirers which are commercial banks with 214 observations on the FDIC-assisted and 32 observations on non-assisted acquisitions. In column (2), we limit the sample of assisted acquisitions to 117 deals where at least 3 bidders attend the auction. Year fixed effects are controlled for in the model, and the F-test shows that the coefficients are jointly significant; nevertheless, for brevity, the coefficients are not reported in the table.

\begin{tabular}{|c|c|c|c|c|}
\hline & $(1)$ & (2) & (3) & (4) \\
\hline & \multicolumn{2}{|c|}{ Whole Sample } & \multicolumn{2}{|c|}{$\begin{array}{c}\text { At least } 3 \text { acquirers attended } \\
\text { the FDIC Auctions }\end{array}$} \\
\hline Variables & Coefficients & Marginal Effects & Coefficients & Marginal Effects \\
\hline Acquirer Relative Size & $\begin{array}{l}0.316^{*} \\
(0.182)\end{array}$ & 0.010 & $\begin{array}{c}0.726^{* *} \\
(0.298)\end{array}$ & 0.020 \\
\hline Acquirer Tier 1 Ratio & $\begin{array}{c}0.058 \\
(0.084)\end{array}$ & 0.002 & $\begin{array}{c}0.161 \\
(0.106)\end{array}$ & 0.004 \\
\hline Acquirer Non-performing Loans & $\begin{array}{r}0.797 * * \\
(0.358)\end{array}$ & 0.024 & $\begin{array}{c}1.487 * * * \\
(0.393)\end{array}$ & 0.041 \\
\hline Acquirer Inefficiency & $\begin{array}{r}0.076^{* *} \\
(0.030)\end{array}$ & 0.002 & $\begin{array}{c}0.223 * * * \\
(0.054)\end{array}$ & 0.006 \\
\hline Acquirer CAMELS Score & $\begin{array}{c}-1.930 * * \\
(0.933)\end{array}$ & -0.058 & $\begin{array}{c}-5.812 * * * \\
(2.105)\end{array}$ & -0.159 \\
\hline Acquirer Core Deposits & $\begin{array}{l}-0.093 \\
(0.088)\end{array}$ & -0.003 & $\begin{array}{l}-0.055 \\
(0.056)\end{array}$ & -0.002 \\
\hline Acquirer Net Interest Margin & $\begin{array}{c}0.678 \\
(0.766)\end{array}$ & 0.020 & $\begin{array}{c}0.389 \\
(0.741)\end{array}$ & 0.011 \\
\hline Acquirer Noninterest Income & $\begin{array}{c}0.105^{* * *} \\
(0.036)\end{array}$ & 0.003 & $\begin{array}{c}0.186 * * * \\
(0.048)\end{array}$ & 0.005 \\
\hline Acquirer Age & $\begin{array}{c}0.080 * * * \\
(0.029)\end{array}$ & 0.002 & $\begin{array}{c}0.200 * * * \\
(0.043)\end{array}$ & 0.005 \\
\hline Constant & $\begin{array}{l}4.386 \\
(4.609)\end{array}$ & & $\begin{array}{l}-15.569^{*} \\
(7.974)\end{array}$ & \\
\hline Year Dummy Variables & Yes & & Yes & \\
\hline Observations & 246 & & 149 & \\
\hline Pseudo R-Squared & 0.740 & & 0.824 & \\
\hline Log-Likelihood & -24.71 & & -13.61 & \\
\hline
\end{tabular}

See table I for variable definitions. Robust standard errors in parentheses. $* * *, * *$ and $*$ indicate significance at $1 \%, 5 \%$ and $10 \%$, respectively. 


\section{Table VII. Financial Strength and Probability of Multiple Acquisitions}

This table reports estimation of Equation (2), using logit techniques. We use the sample of observations on commercial banks that acquire failed banks through the FDIC-assisted acquisitions. In columns (1) and (2), We use the dummy variable for multiple takeovers during the study period, i.e. 2007:Q1-2016:Q3, as the dependent variable. In columns (3) and (4), the dependent variable is the dummy variable for multiple takeovers in a given quarter. Year fixed effects are controlled for in the model, and the F-test shows that the coefficients are jointly significant; nevertheless, for brevity, the coefficients are not reported in the table.

\begin{tabular}{|c|c|c|c|c|}
\hline & (1) & (2) & (3) & (4) \\
\hline & \multicolumn{2}{|c|}{ Multiple takeovers during the study period } & \multicolumn{2}{|c|}{ Multiple takeovers in a given quarter } \\
\hline Variables & Coefficients & $\begin{array}{l}\text { Marginal Effects } \\
\text { at the Mean }\end{array}$ & Coefficients & $\begin{array}{c}\text { Marginal Effects } \\
\text { at the Mean }\end{array}$ \\
\hline Relative Size & $\begin{array}{c}0.032 * * * \\
(0.012)\end{array}$ & 0.006 & $\begin{array}{c}0.023 \\
(0.021)\end{array}$ & 0.002 \\
\hline Acquirer Tier 1 Ratio & $\begin{array}{l}0.030 \\
(0.037)\end{array}$ & 0.006 & $\begin{array}{c}0.105^{* * *} \\
(0.040)\end{array}$ & 0.010 \\
\hline Acquirer Non-performing Loans & $\begin{array}{l}0.173^{* *} \\
(0.070)\end{array}$ & 0.034 & $\begin{array}{c}0.081 \\
(0.070)\end{array}$ & 0.007 \\
\hline Acquirer Inefficiency & $\begin{array}{c}0.004 \\
(0.011)\end{array}$ & 0.001 & $\begin{array}{c}0.003 \\
(0.017)\end{array}$ & 0.000 \\
\hline Acquirer CAMELS Score & $\begin{array}{l}-0.219 \\
(0.305)\end{array}$ & -0.044 & $\begin{array}{l}-0.125 \\
(0.516)\end{array}$ & -0.011 \\
\hline Acquirer Core Deposits & $\begin{array}{c}0.020 \\
(0.018)\end{array}$ & 0.004 & $\begin{array}{c}0.016 \\
(0.023)\end{array}$ & 0.001 \\
\hline Acquirer Net Interest Margin & $\begin{array}{c}0.528^{* *} \\
(0.269)\end{array}$ & 0.105 & $\begin{array}{c}0.173 \\
(0.398)\end{array}$ & 0.016 \\
\hline Acquirer Noninterest Income & $\begin{array}{l}0.028^{* *} \\
(0.013)\end{array}$ & 0.006 & $\begin{array}{c}0.010 \\
(0.014)\end{array}$ & 0.001 \\
\hline Acquirer Age & $\begin{array}{l}-0.007 * \\
(0.004)\end{array}$ & -0.001 & $\begin{array}{l}-0.001 \\
(0.007)\end{array}$ & -0.000 \\
\hline Constant & $\begin{array}{c}7.574 * * * \\
(2.365)\end{array}$ & & $\begin{array}{c}-18.602 * * * \\
(3.177)\end{array}$ & \\
\hline Year Dummy Variables & Yes & & Yes & \\
\hline Observations & 183 & & 167 & \\
\hline Pseudo R-Squared & 0.154 & & 0.142 & \\
\hline Log-Likelihood & -106.3 & & -52.51 & \\
\hline
\end{tabular}

See table I for variable definitions. Robust standard errors in parentheses. $* * *, * *$ and $*$ indicate significance at $1 \%, 5 \%$ and $10 \%$, respectively. 